\title{
OBSERVATIONS ON BRITISH AND NORWEGIAN HYDROIDS AND THEIR MEDUSAE
}

\author{
By W. J. Rees, M.Sc.
}

Research Assistant at the Plymouth Laboratory

(Text-figs. I-I2)

\section{CONTENTS}

Introduction

Bougainvillia muscoides (M. Sars I846)

Systematic Discussion on Perigonimus

The Genus Rhizorhagium M. Sars 1877

Rhizorhagium roseum $M$. Sars 1877

Rhizorhagium sarsii (Bonnevie 1898)

Rhizorhagium album $\mathrm{n} . \mathrm{sp}$.

The Genus Leuckartiara Hartlaub I9I4

The Hydroid of Leuckartiara octona (Fleming 1823)

Leuckartiara abyssi (G. O. Sars I873)

Thamnostoma russelli $\mathrm{n} . \mathrm{sp}$.

The Hydroid of Euphysa aurata Forbes 1848

Campanulina paracuminata n.sp. . . . . . . . . . . . . . 33

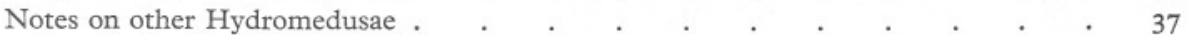

Boreohydra simplex Westblad 1937 . . . . . . . . . . . . . . . 37

Stauridium productum Wright 1858 . $\quad . \quad$. $\quad . \quad . \quad . \quad . \quad . \quad . \quad . \quad . \quad 37$

Staurocoryne filiformis Rees 1936 . . . . . . . . . . . . . . . . 38

Summary

References

\section{INTRODUCTION}

This paper contains observations on British and Norwegian Hydromedusae made at Plymouth and Bergen respectively. Observations on Campanulina paracuminata n.sp., Rhizorhagium album n.sp., Staurocoryne filiformis Rees I936 and on the hydroid of Leuckartiara octona (Fleming) were made at Plymouth during 1936 and 1937 . The observations on the Norwegian forms are some of the results of a six weeks' stay at the Bergens Museum Biological Station at Herdla near Bergen.

The main object of my visit to Herdla was to work out the life history of Perigonimus muscoides $M$. Sars I846. In addition to this life history, observations were made on several other interesting hydroids and medusae, of which the following species are described in this paper: Leuckartiara abyssi (G. O. Sars I873), Rhizorhagium roseum M. Sars 1877, Thamnostoma russelli 
n.sp., Corymorpha annulicornis M. Sars 1859. Notes are included on Stauridium productum Wright 1858 , and Boreohydra simplex Westblad 1937.

I am indebted to the Challenger Society for a grant to cover my expenses at Bergen. I also wish to express my thanks to the following: to Professor August Brinkmann, Director of the Biological Station at Herdla, who gave me every facility to pursue my work; to Amanuensis D. Rustad for much help in collecting material and in setting up special apparatus; to Dr Jöran Hult (Uppsala) for the use of his "sledge dredge" at Herdla and for material from Northern Norway. My thanks are also due to Mr F. S. Russell for helpful criticism at all times.

\section{Bougainvillia muscoides (M. Sars I846)}

\section{Synonym: Perigonimus muscoides M. Sars 1846.}

This species was first described by Michael Sars (1846) as Perigonimus muscoides. He found it growing on the test of Ascidia mentula Linn. and on the tubes of Tubularia indivisa from depths between 20 and 30 fathoms in the Mangerfjord. It has since been found by a number of investigators from Scandinavian seas and the hydroid is accurately figured by Jäderholm (I909). Stechow (I923) has described a closely related species from the Mediterranean under this name. A careful comparison of the descriptions of this hydroid and those of better known so-called "Perigonimus" hydroids convinced Stechow that the latter were not cogeneric with the genotype, $P$. muscoides. Rees \& Russell (1937) accepted Stechow's revision in part and accordingly removed certain species from Perigonimus. Further revision of the British species was impossible without knowing for certain what the medusa of $P$. muscoides was, and it was this which prompted me to go to Bergen to search for it.

During my stay at Bergen numerous colonies of this hydroid were found and its medusa proved to be a Bougainvillia. Perigonimus therefore becomes a synonym of Bougainvillia, and the species must henceforth be called B. muscoides (M. Sars I846).

B. muscoides was found on the first day of my stay at Herdla. It was taken at Bognøstrømmen in the Mangerfjord living on the test of Ascidia mentula Linn. dredged from depths between ro and $80 \mathrm{~m}$. It was in this fjord that Sars originally found the species growing on Ascidia mentula and on the tubes of Tubularia indivisa.

Below are given my records of this hydroid:

2. viii. 37. Bognøstrømmen, Mangerfjord. Four colonies, on four out of five specimens of Ascidia mentula dredged between 10 and $80 \mathrm{~m}$. One colony had medusa buds and a few medusae were liberated in the laboratory on the same day.

6. viii. 37. South of North Bratholmen, Hjeltefjord, ca. Ioo m. One small poorly developed colony, with a few medusa buds, growing on Sertularella gayi.

I9. viii. 37. Bognøstrømmen, Mangerfjord, 40-50 m. A large well-developed colony, with numerous medusa buds, growing over the stems of Tubularia indivisa. A colony of Rhizorhagium roseum M. Sars was growing over both hydroids. 
THE HYDROID. The colonies consist of upright rhizocaulome formations arising at intervals from a network of stolons running over the test of the ascidian or over the tubes of the Tubularia. The appearance of the colonies is quite distinct from other Norwegian hydroids. The upright branches are thicker and less branched, and the secondary branches are shorter and fewer than in young stages of other Bougainvillia hydroids. Sars gives an excellent coloured figure of the living hydroid and Jäderholm (I909) gives a good figure of the rhizocaulome formation.

The stems reach a height of $2 \mathrm{~cm}$. and are covered by a chitinous perisarc. When the colony is young only the central tube is present. This thickens in diameter with age, and stolons from the base creep up along it on all sides so that there may be four to seven auxiliary tubes in addition to the main stem. A thick polysiphonous rhizocaulome is thus formed (Fig. I a). A similar condition has been described by Browne (I907) in Bimeria biscayana.

The central tube is $0.25-0.3 \mathrm{~mm}$. in diameter and the auxiliary tubes are O. I mm. Both can give rise to hydranths. The polyps are somewhat irregularly distributed; they may occur terminally, at the ends of branches or laterally on short stems; sessile polyps also occur on the rhizocaulome itself. The hydranths are typical of Bougainvillia, with a prominent conical hypostome and a whorl of filiform tentacles. The terminal hydranths are usually the largest, $0.5-$ $\mathrm{I} .0 \mathrm{~mm}$. in length and $0.2-0.3 \mathrm{~mm}$. in diameter. The lateral hydranths (Fig. I $a$ ) are smaller and have eight to eleven tentacles, a feature also noted by Sars (I846). Unless the colony was very old the terminal hydranth originated from the central tube. In some of the oldest colonies seen, however, the coenosarc of the central tube had disappeared and a new terminal hydranth had developed from an auxiliary tube.

The perisarc of a stem supporting a hydranth may be slightly wrinkled and enlarges a little distally to form a slight cup into which the posterior third of the hydranth can contract. The coenosarc narrows gradually below this point to form a thin tube. The smallest hydranths, which are almost sessile on the rhizocaulome, arise from the sides of the central and auxiliary tubes. Their stalks are usually thin and have about the same diameter as the auxiliary tubes. These hydranths appear to be young ones in which the stalk later becomes much thicker and longer.

The most remarkable feature of this hydroid is the great number of medusa buds. These arise directly from the rhizocaulome and its branches (Fig. I $a$ ). They are frequently situated in rows on the auxiliary tubes and are almost sessile, having only very short stalks. A fruiting colony with its reddish polyps and the red and white medusa buds is a beautiful object when seen under a low-power lens. The largest buds are $0.4 \mathrm{~mm}$. long by $0.3 \mathrm{~mm}$. in diameter. When the medusa bud is almost fully developed the reddish manubrium and the brownish bulbs of the four tentacles show clearly through the thin hyaline perisarc which protects the bud. The last structures to develop in the bud are the four single oral tentacles on the manubrium. Sars' original 
colony had medusa buds, but these were not quite fully developed, and the bud which he pressed out of its envelope (Sars, I846, tab. I, fig. 2I) showed the manubrium and the four marginal tentacles, but not the four oral tentacles.

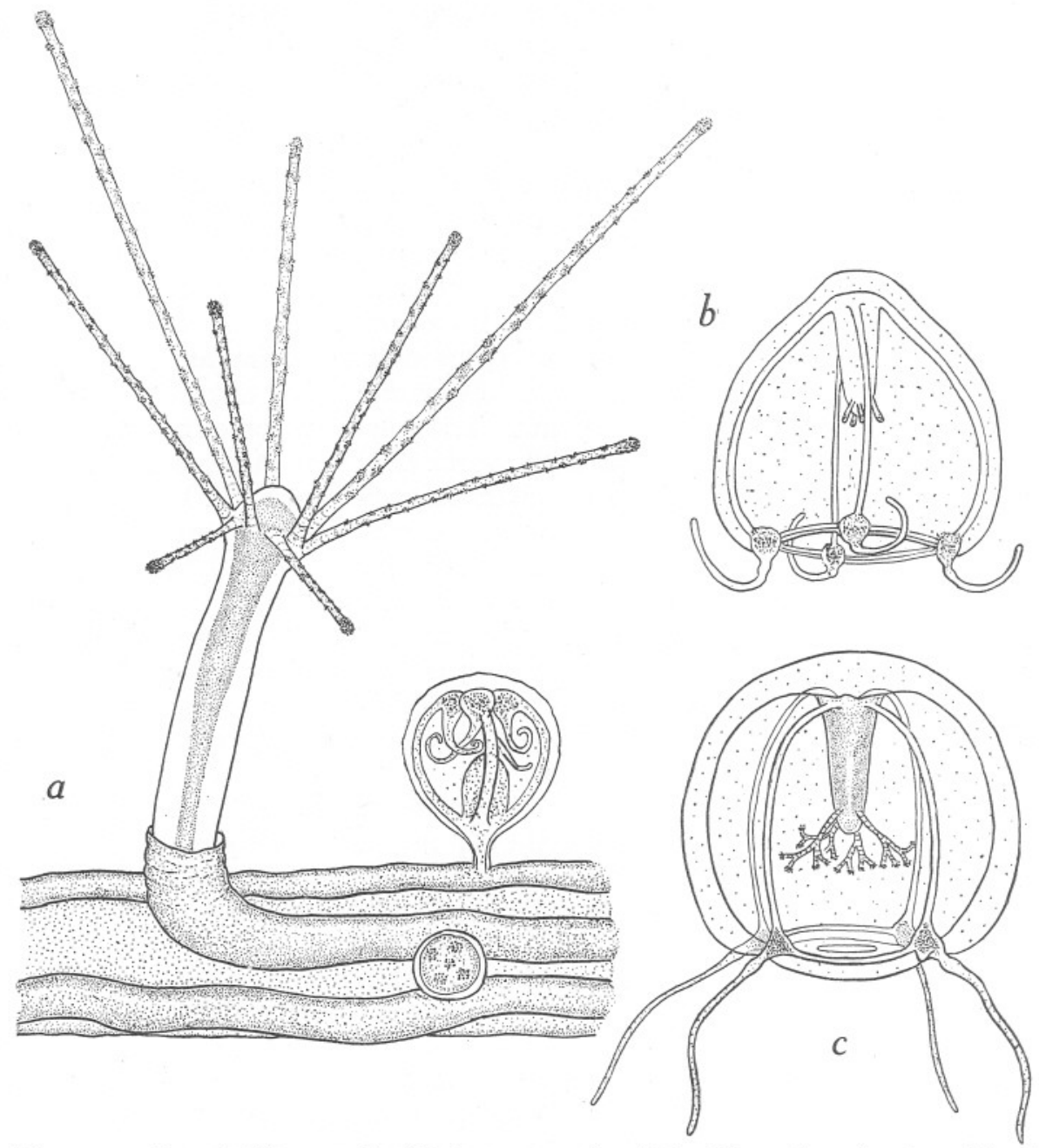

Fig. I $a-c$. Bougainvillia muscoides M. Sars: $a$, portion of the rhizocaulome bearing a lateral hydranth and two medusa buds, Herdla, 7. viii. $37 ; b$, newly liberated medusa, Herdla, 3. viii. $37 ; c$, young medusa obtained from the plankton in the Hjeltefjord, 30. viii. 37.

Allman (I863) was thus led to believe that the medusae were of a similar type to those of Atractylis repens (Wright, 1857) and accordingly placed this and other similar species in Perigonimus. Later authors, with the exception of Stechow (1923) and Rees \& Russell (I937), have followed Allman and have referred this species to the Pandeidae (Tiaridae). 
The newly liberated medusa (Fig. I $b$ ) is bell-shaped, as high as wide, with a diameter of $0.55-0.65 \mathrm{~mm}$. The jelly is thin, but thicker nearer the apex than elsewhere, and there are numerous scattered nematocysts on the exumbrella. The velum is well developed. The stomach is short and conical, barely reaching to half the height of the subumbrellar cavity. Four unbranched oral tentacles, $0.07 \mathrm{~mm}$. in length, with a few terminal nematocysts, arise above the mouth margin. The four radial canals and ring canal are narrow. There are four welldeveloped perradial bulbs, each with a single tentacle. There is a slight swelling at the base of each tentacle just before it joins the bulb, and this appears to be characteristic of this medusa. There are no ocelli. The reddish colour of the manubrium, so conspicuous in the bud, is less brilliant in the newly liberated medusa, but the reddish brown pigment in the tentacle bulbs is quite distinct. The oral tentacles of one medusa kept for a few days in the laboratory were beginning to branch. This medusa measured $0.85 \times 0.8 \mathrm{~mm}$.

I obtained a young medusa (Fig. I $c$ ) from plankton from the Hjeltefjord on August 30 1937. This was in a later stage of development than those I had been able to rear. The medusa was immature and measured $\mathrm{I} .55 \mathrm{~mm}$. high and $\mathrm{r} .65 \mathrm{~mm}$. in diameter. The oral tentacles on the manubrium were twice dichotomously branched. On each marginal bulb there was a rudiment of a second tentacle developing on the right side of the existing one. Each marginal tentacle possessed the characteristic swelling at its base near the bulb. There were no ocelli. The colour of the manubrium varied from reddish orange to red, and the tentacle bulbs were yellowish brown.

The medusa was identified as Bougainvillia nordgaardi (Browne). Kramp \& Damas (1925) have described various stages in the development of this medusa. My medusa from the plankton corresponds to their Stage 2. The stage which Kramp \& Damas call Stage I is a medusa several days old in which the oral tentacles have become branched. Their medusa appears to have lost its four tentacles.

The similarity between the medusa taken from the plankton and those reared from the hydroid points to the extreme probability that the medusa of B. muscoides is B. nordgaardi (Browne).

\section{Systematic Discussion on PeRIGONIMUS}

The discovery that the medusa of Perigonimus muscoides is a Bougainvillia is of considerable importance in the classification of those species which have up to now been referred to the genus Perigonimus. It necessitates the revision of all so-called "Perigonimus" hydroids because Bougainvillia muscoides was the genotype of Perigonimus.

Since Bougainvillia is the older generic name, Perigonimus becomes its synonym and the latter name can no longer be used for those species of "Perigonimus" whose medusae are not Bougainvillids. Stechow (I923) expressed the opinion that $P$. muscoides was not cogeneric with the other species 
of "Perigonimus" then referred to the genus, and accordingly restricted the name Perigonimus to this species and included provisionally also Bimeria biscayana Browne 1907. He proposed the use of the medusa name Leuckartiara Hartlaub I9I4 for the hydroids producing medusae with two opposite tentacles. Two of these species have since been removed to the genus Amphinema Péron \& Lesueur I 809 by Rees \& Russell (I937). The advisability of using the generic name Leuckartiara will be discussed under the account of this genus.

Any revision of the genus Perigonimus in its widest sense must also include the genera Atractylis Wright I858, Wrightia Allman 1872, Dinema van Beneden I866, Rhizorhagium M. Sars I877, Gravelya Totton I930, and to a certain extent Bougainvillia Lesson I836. It is necessary to clarify the position of these forms with fixed gonophores at present referred to some of these genera.

The differences between the trophosomes of Bougainvillia and Leuckartiara are very slight. Usually the Bougainvillia hydroid is more branched, but there are exceptions, and the presence of a dilatation of the perisarc around the base of the hydranth in many species of Bougainvillia makes them very difficult, if not at present impossible, to distinguish from Leuckartiara. However, their medusae belong to the Bougainvilliidae and the Pandeidae. To which of these families are we to refer the non-medusa-bearing forms? Our knowledge of many of these is very incomplete at the present, and it would be inadvisable to put them into either Leuckartiara or Bougainvillia. The only alternative is to put them into a genus of their own until their exact systematic position can be ascertained.

There are several generic names which come under consideration. Allman (I872) restricted the genus Atractylis Wright I857 to A. arenosa Alder (I862), which has fixed gonophores. Later he discarded Atractylis because it was preoccupied by a plant of that name. In its place he erected his genus Wrightia, although he knew it was preoccupied by Wrightia Agassiz (I862), a genus synonymous with Campanulina van Beneden which had priority over it. Totton (I930) has selected Atractylis ramosum (= Bougainvillia ramosum) as the genotype of Atractylis, so that this genus is now sunk under Bougainvillia Lesson.

The oldest valid* generic name is Rhizorhagium M. Sars 1877 , and this genus is discussed further below.

\section{The Genus Rhizorhagium M. SARS I877}

Synonyms: Wrightia E. S. Russell 1907.

Gravelya Totton 1930.

The genus Rhizorhagium was erected by Sars (1877) for a Norwegian species which he called $R$. roseum. He laid particular stress on the fixed nature of the gonophores as the chief character of his genus. Bonnevie (I898) described a new species, Perigonimus sarsii, which together with Rhizorhagium roseum she

* Dinema van Beneden 1866 is preoccupied by Dinema Fairmaire I849, an insect genus. 
referred to the genus Perigonimus. Stechow (1923) referred the above, together with Perigonimus antarcticus Hickson \& Gravely 1907 and Atractylis coccineus Wright (see Russell, 1907), to Rhizorhagium.

The last of these, as will be shown later, is in all probability identical with $R$. roseum Sars. For reasons already given (see p. 6) these species hitherto referred by some authors to "Perigonimus" must be kept separate from Bougainvillia and Leuckartiara until later work with living material reveals their exact systematic position.

Levinsen (1892) described Rhizorhagium roseum from Greenland as Garveia groenlandica (Broch, I9I6). This raises the question whether all the above species should not be included in the genus Garveia Wright I859. The chief characters of Garveia as defined by Allman (1872) were the well-developed branching hydrocaulus, the fusiform hydranth with a whorl of filiform tentacles around a conical proboscis, and reproduction by means of fixed gonophores borne on short stalks. Torrey (I902) united Garveia with Bimeria Wright I859, a step which I cannot but regard as retrogressive (see p. 25). He referred Perigonimus formosus Fewkes, an unbranched form closely resembling Rhizorhagium roseum, to his genus "Bimeria".

The creeping hydrorhiza with the simple unbranched stems each bearing a single hydranth is characteristic of all these species with fixed gonophores previously referred to Perigonimus, and I feel hesitant in referring them to a genus such as Garveia where the hydrocaulus is typically a well-developed branched tree-like growth. For the present therefore it appears best to retain Rhizorhagium for the following species: R. roseum, Perigonimus sarsii, $P$. antarcticus, $P$. formosus Fewkes and a new species Rhizorhagium album to be described later.

The genus Gravelya was founded by Totton (1930) for Perigonimus antarcticus and was defined as follows: "Monoecious Bougainvillidae with numerous dimorphic cryptomedusoid gonophores scattered over the hydrorhiza." His genus clearly falls into the synonymy of Rhizorhagium. No stress can be laid on the word "Bougainvillidae" in his definition because the trophosome is distinctly like that of the hydroid of Amphinema dinema. Neither can the degree of development of the gonophore be stressed as a generic character; it is more suitable as a specific one.

The genus may be defined as follows:

Polyp stems, simple, unbranched and arising either from a creeping anastomosing hydrorhiza or from a weakly developed rhizocaulome formation; polyps clavate or fusiform with a single whorl of filiform tentacles around the base of a conical proboscis and partially retractile into a slight dilatation of the perisarc. Gonophores fixed, borne on short stalks on the hydrorhiza or on the rhizocaulome formation.

The above diagnosis does not differ in essentials from that of Sars. The specific characters of Rhizorhagium roseum which were included by Sars have been omitted and the definition of the genus emended so as to include Peri- 
gonimus sarsii Bonnevie I898 and Rhizorhagium album n.sp.; Perigonimus antarcticus falls naturally into the genus.

Rhizorhagium roseum $M$. Sars 1877

Synonyms: ? Atractylis coccineus Wright I86I.

Perigonimus roseus Bonnevie 1898.

Atractylis coccineus Russell 1907.

Wrightia coccineus Russell I907.

Garveia groenlandica Levinsen 1892.

Perigonimus (Rhizorhagium) roseus Broch 1928.

This species I found at Herdla on several occasions. Colonies were found growing on Tubularia indivisa at Rong Sund and Bognøstrømmen. One colony from Bognøstrømmen was creeping over the stems of Bougainvillia muscoides.

The measurements of a fruiting colony are given below:

Measurements in $\mathrm{mm}$.

$\begin{array}{llll}\text { Length of hydranth } \ldots & \ldots & \ldots & 0.4-0.45 \\ \text { Diameter of hydranth ... } & \ldots & \ldots & 0.3-0.35 \\ \text { Length of hydrocaulus } & \ldots & \ldots & 3.0-3.5 \\ \text { Diameter of hydrocaulus } & \ldots & \ldots & 0.12-0.2 \\ \text { Length of gonophore ... } & \ldots & \ldots & 0.9-1.2 \\ \text { Diameter of gonophore } & \ldots & \ldots & 0.5-0.75 \\ \text { Length of gonophore stalk } & \ldots & \ldots & 0.35-0.7\end{array}$

According to Broch (I9I6) the stalks may reach a length of $12 \mathrm{~mm}$. in larger colonies. The tentacles vary from six to twelve in number. The whole colony when alive had a rosy colour. Sars (I877) and Jäderholm (I909) give excellent figures of this hydroid.

I can find no fundamental difference between the descriptions of the Atractylis coccineus described by Russell (1907) and Rhizorhagium roseum. Sars (I877) states that the gonophore is naked, while that of Russell's species is covered by a thin perisarc. A close examination of living material at Herdla revealed the presence of this thin perisarc. Broch (I9I6) also found a perisarc covering the gonophore, and states that it flays off when the gonophore is fully grown. The hydranth in Atractylis coccineus Russell is nearly always bent at an obtuse angle with the stalk, and the same characteristic has been figured for Rhizorhagium roseum by Sars \& Jäderholm. It was also characteristic of all my colonies from Herdla. The habitat, the colour, the wrinkling of the perisarc, and the short-stalked gonophore are alike in both, and there seems little doubt that they are identical.

Whether this species is the same as the original Atractylis coccineus described by Wright (I86I) is impossible to tell because the original description lacked a figure and no gonophores were found. It is therefore noted as a doubtful synonym of Rhizorhagium roseum.

The species is very common around the Norwegian coast and has been found in the White Sea and Novaya Zembla (Schydlowsky, I90I). It was first recorded 
from Greenland by Levinsen (I893) as Garveiagroenlandica. A re-examination of the original specimen by Broch (1916) showed that the specimen in question should have been referred to Rhizorhagium roseum. Jäderholm (1909) has given an excellent figure and a list of Swedish records. There are numerous records from east and west Greenland (see Kramp, I914, I932 $a, b$ ). According to Fraser (1937) it is found on the Pacific coast of North America. To these we must add Russell's record from Millport on the west Scottish coast.

\section{Rhizorhagium sarsii (Bonnevie I898)}

\section{Synonym: Perigonimus sarsii Bonnevie.}

This hydroid has only been recorded from Norway. Bonnevie found it at Christiansund, but states that it had been previously found in the Oslofjord by G. O. Sars and later by Greig at Bognøstrømmen in the Mangerfjord. It has since been found by Broch (1905), one colony on Portunus depurator and another on Corystes cassivelaunus. A redescription of this species from living material is much to be desired. Several points in Miss Bonnevie's description need amplifying and verifying. During my stay at Herdla I spent much time searching for this hydroid at Bognøstrømmen, but did not succeed in finding it. I did, however, find a colony of Rhizorhagium roseum growing over the stems of Bougainvillia muscoides. When alive the stolons of the two hydroids could easily be distinguished by their colour, but when preserved the stolons were indistinguishable. It appears possible to me that a well-developed colony of Rhizorhagium roseum growing over a dead colony of Bougainvillia muscoides could easily be mistaken for Rhizorhagium sarsii.

\section{Rhizorhagium album n.sp.}

A very small hydroid found by Mr F. S. Russell growing on small weeds in a rock pool at Newquay, Cornwall, has proved to be a new species. Mr Russell kindly gave me the hydroid to rear and describe. When found the hydroid appeared to be a creeping or a juvenile form of a Bougainvillia or a species of "Perigonimus". Styloid gonophores, however, were developed. The species could not be referred to any known species with certainty and has therefore been described as new. It approaches nearest to and may be identical with Eudendrium pudicum Van Beneden I866. Van Beneden regarded his species as identical with Trichydra pudica Wright, which, however, is quite a different kind of hydroid from the one he figures. Gonophores were not observed by Van Beneden, and there is no certainty that his species is identical with mine. Eudendrium pudicum Van Beneden is therefore noted as a doubtful synonym. The systematic position of this species is discussed later in this paper.

Three small colonies were found on a filamentous alga. The polyps could be distinguished with the naked eye as minute white specks. The colonies were not reproducing and did not do so until they had been four months in captivity.

The stolons creep over the alga or over each other and sometimes branch (Fig. 2 a). They are covered by a thin transparent perisarc which is irregularly 
wrinkled. They are $0 . \mathrm{I} \mathrm{mm}$. in diameter. The stems are very short, and sometimes the polyps are subsessile. The stems, like the stolons, are irregularly wrinkled and rarely exceed $0.3 \mathrm{~mm}$. in length. The perisarc of the stems ex-

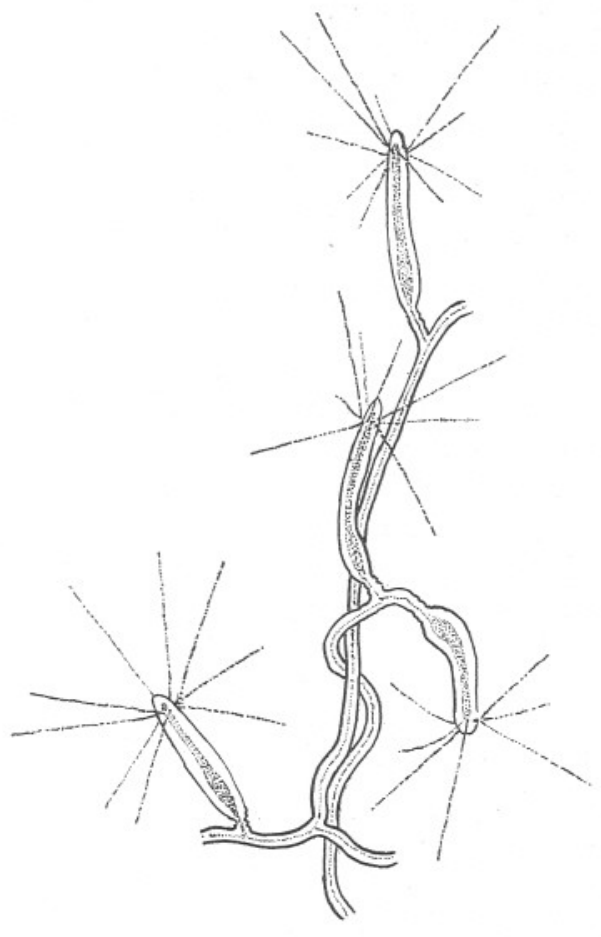

$a$
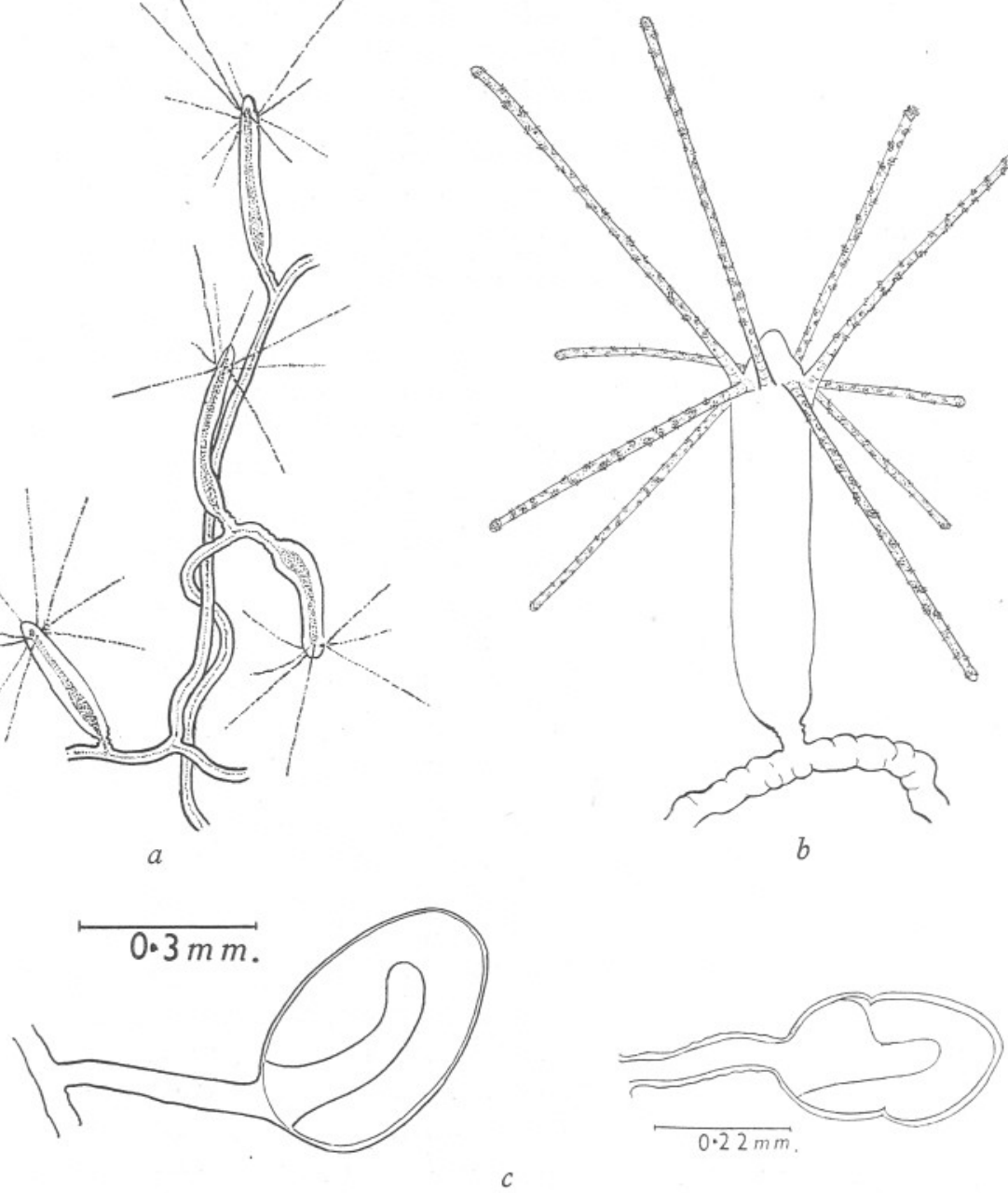

Fig. 2 a-c. Rhizorhagium album n.sp.: a, general appearance of a colony kept in the Plymouth Laboratory, 5. iv. $37 ; b$, single hydranth, 6. iv. $37 ; c$, male gonophores.

pands to form a close-fitting pseudohydrotheca around the base of the hydranth. How far it extends on the hydranth itself was very difficult to determine. The hydranths are tubular with a single whorl of six to ten filiform tentacles around a small but distinct hypostome (Fig. $2 b$ ). The polyps vary from 0.35 to $0.55 \mathrm{~mm}$. in length with a transverse diameter of $0 . \mathrm{I}-\mathrm{O} . \mathrm{I} 4 \mathrm{~mm}$. 
The polyps themselves are white in colour with a light brown endoderm. Gonophores were observed developing on April 3 1937. These were fully developed seven days later. Others were developed later in the year. On all three colonies only male gonophores were developed (Fig. $2 c$ ). These were typical styloid gonophores borne on fairly long stalks $0.3-\mathrm{I} \cdot 0 \mathrm{~mm}$. long. The largest gonophore seen had a diameter of $0.4 \mathrm{~mm}$.

This species differs in many characters from other species now placed in Rhizorhagium. The hydranths are almost sessile, and the gonophores stalked, as compared with the long-stalked hydranths and almost sessile gonophores in typical species of Rhizorhagium. Owing to the unsatisfactory state of our knowledge of the Bougainvillia-Leuckartiara type of hydroids I feel hesitant in erecting a new genus to take this species and provisionally therefore include it in Rhizorhagium.

The following is a concise definition of the new species:

\section{Rhizorhagium album n.sp. (Fig. 2)}

Synonym: ? Eudendrium pudicum van Beneden 1866.

Stems and stolons covered by a distinct, irregular, and sometimes faintly wrinkled perisarc. Hydranths tubular with a whorl of six to ten filiform tentacles around a bluntly conical proboscis and borne on very short hydrocauli.

Gonophores: male gonophores are styloid, borne on distinct stalks. Female gonophores unknown.

Distribution: Newquay, coast of north Cornwall.

\section{The Genus LeUckartiara Hartlaub I9I4}

\section{Hydroid Synonyms: Atractylis Wright 1858 (in part). \\ Perigonimus Allman I863 (in part). \\ Dinema van Beneden 1866.}

The genus Leuckartiara was erected by Hartlaub (19I4) for three species of pandeid medusae. The hydroids of this and allied genera had been referred by Allman (I863, I864 b) and later workers to the genus Perigonimus Sars. It has been shown earlier in this paper that Perigonimus can no longer be used for hydroids of this type which produce pandeid medusae. Stechow (I923) has used the name Leuckartiara for hydroids of this type, which produce medusae with two tentacles. Great care, however, must be taken to use this name correctly, because a great many of the so-called "Perigonimus" hydroids produce medusae which do not belong to the medusa genus Leuckartiara; for example, Perigonimus serpens Allman $\mathrm{I}^{863}$ is the hydroid of Amphinema dinema Péron \& Lesueur. Apart from the hydroids at present referred to the genus Amphinema, the only two hydroids, producing pandeid medusae, whose life histories are known with certainty are Perigonimus repens (which is the 
hydroid of the medusa Leuckartiara octona) and Perigonimus cirratus Hartlaub I914, of which the medusa is Halitholus cirratus. Both hydroid and medusa should be called $H$. cirratus.

Those species whose newly liberated medusae with two opposite tentacles are obviously pandeid medusae should, I think, be referred provisionally to Leuckartiara as "Leuckartiara" spp. Perigonimus nudus Stechow I9I9 obviously has no affinities with Bougainvillia or Leuckartiara. Indeed, as Stechow himself observes it is probably related either to Campanopsis, Hydranthea or to Halecium; it needs a new generic name.

I have provisionally included Perigonimus abyssi G. O. Sars 1873 in Leuckartiara as L. abyssi.

The Hydroid of Leuckartiara octona (Fleming I823).

The hydroid of Leuckartiara octona (Fleming) is best known by the name Perigonimus repens (Wright I857). It is one of the commonest species occurring in British waters. The species is very variable in form, and this led earlier workers to regard certain types of growth as distinct species. The various descriptions of this hydroid are very scattered in the literature, and there is no single adequate description. It is therefore considered desirable to redescribe this species and to record the variations to which it is subject under different conditions of habitat. The medusa is well described by Hartlaub (I9I4).

HISTORICAL. The species was originally described by Wright (I857) as Eudendrium pusillum. He found it growing on the back and walking legs of spider crabs and on sertularians. At the same time he described another species, E. sessile, which he found growing on shells from deep water in the Firth of Forth and declared that the medusae on liberation seemed to be identical. It will be shown later in this paper that $E$. sessile is the creeping form of $E$. pusillum. A year later, in I858, Wright refers to his E. pusillum as E. repens, though he gives no reason for the change of the name. A search through the literature reveals that a species of Halecium was described by Sars (I857) as Eudendrium pusillum. Perhaps this is the reason for the change of name.

In the same paper (1858) Wright dismembers the old genus Eudendrium Erhenberg into Eudendrium proper with a trumpet proboscis and Atractylis. He referred his two "Eudendrium" species to this latter genus with E. ramosum (van Beneden, Dalyell) (=Bougainvillia ramosa) as the genotype. Allman (I863, I864) removed Wright's two'species to the genus Perigonimus Sars I846, and to this genus he also referred a new species, $P$. minutus, which he found living on the operculum of Turritella communis Lamarck from the Shetland Islands. Opinion is divided as to whether this species is synonymous with Perigonimus repens. Hincks (I868) lists it as a synonym of $P$. repens, but Allman (I872) separates them again.

The species described by van Beneden (1866) as Dinema slabberi is undoubtedly this species. 
The next important contribution to the life history is that of Hartlaub (I895) who succeeded in rearing the medusa to a stage when it could be recognized as a young pandeid (Tiara). He also found medusa buds developing from both the stolon and the hydrocaulus, which made him doubtful of the identity of his species. Later (1914) he refers it to Perigonimus repens and gives the synonymy of the species and an excellent description of the medusa for which he erected the genus Leuckartiara.

Broch (I9I6) discussed the distribution of the species and the nature of the pseudohydrotheca. Stechow (see p. II) was the first to separate this species from Perigonimus. In later papers he refers to the hydroid as Leuckartiara pusilla (Stechow, I929).

Records of this hydroid are very numerous, but only the more important references are given in the bibliography.

THE HYDROID. The hydroid is nearly always found living in association with other animals. It occurs chiefly on the shells of molluscs and on the legs and carapace of various crabs, but has been found growing on a number of other animals. Colonies vary greatly in their mode of growth, depending on the nature of the host and on the substratum. I propose to describe below typical colonies from the shell and operculum of Turritella communis Lamarck, Scaphander lignarius (Linn.), Corystes cassivelaunus (Pennant), and Agonus cataphractus.

Shells of living Turritella communis dredged from Rame mud frequently carried small colonies with almost sessile hydranths arising from a creeping reticulate stolon $0.05 \mathrm{~mm}$. in diameter. The hydranths were small (Figs. $3 a, b$ ), rarely with a height (to top of hypostome) of more than $0.5 \mathrm{~mm}$. They possessed a distinct conical hypostome and a single whorl of 4-8 filiform tentacles. The close-fitting perisarc of the hydranth was thin and reached as far as the base of the tentacles. Medusa buds were borne at intervals on the creeping stolon. Like the hydranths they were also almost sessile with a very short stalk. The newly liberated medusae were typical specimens of young Leuckartiara; some were reared in the Laboratory until the gonads began to appear when the species could be recognized for certain as Leuckartiara octona.

Colonies from the opercula of living Turritella shells and those on the "upper sides" of shells of the same species inhabited by small hermit crabs were very similar in appearance (Figs. $3 a, c$ ). A portion of a typical colony growing on a shell inhabited by a hermit crab is shown in Fig. $4 a$. The stems were fairly long, smooth, sometimes ringed at the base, generally unbranched, but occasionally a single stem bore two hydranths. The total height of the stems was $\mathrm{I} \cdot 5-2.5 \mathrm{~mm}$. In this colony young and old polyps were found. The hydranths were fusiform with a loose-fitting, irregularly wrinkled perisarc, reaching as far as the base of the tentacles. Thelargesthydranths had a length (to top of hypostome) of $0.5 \mathrm{~mm}$. and had 8-Io tentacles. The smallest hydranths had 4-8 tentacles. Medusa buds were borne on both hydrocaulus and hydrorhiza. The medusa buds had distinct stalks with a smooth or wrinkled perisarc. The 
stalks were never longer than the medusa buds. The "sides" and "lower side" of the shell showed transitional polyps between the sessile form and the

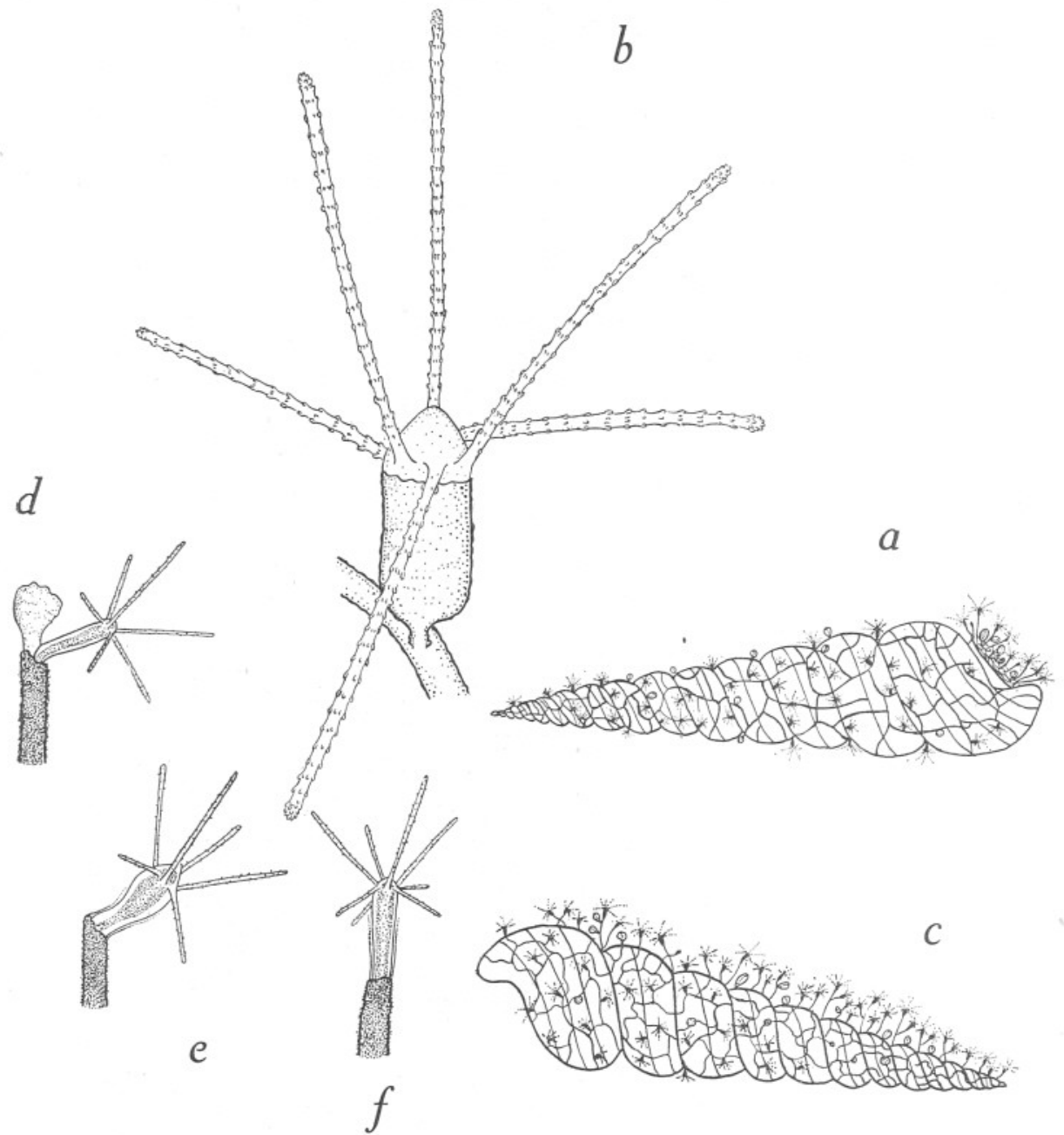

Fig. $3 a-f$. Leuckartiara octona: a, creeping form of the hydroid on a shell of Turritella communis with the branched form on the operculum, 2 . vii. $37 ; b$, single hydranth of the creeping form on a living Turritella shell, I2. iii. $36 ; c$, the branched form of the hydroid on the "upper side" of a shell of Turritella inhabited by a hermit crab, with the creeping form on the "lower side", I6. iii. $36 ; d-f$, regeneration of a new hydranth from an old stem growing on Scaphander lignarius, 17. ii. 37; all from Plymouth.

branched form on the upper part of the shell (Fig. $4 b$ ). Medusae were also reared from these colonies and they developed into typical Leuckartiara octona medusae.

Colonies living on the shells of Scaphander lignarius usually grow on the 
posterior part of the shell. The stolons form an open network. The stems are long, of uniform thickness and covered with a layer of fine mud particles. The stems bear one or two hydranths. The hydranths are usually small, rarely having a diameter much greater than that of the stem. The hydranths frequently die down and new ones are formed from the side of the hydrocaulus just below the position of the old hydranth (Fig. $3 d, e, f$ ). Medusa buds are

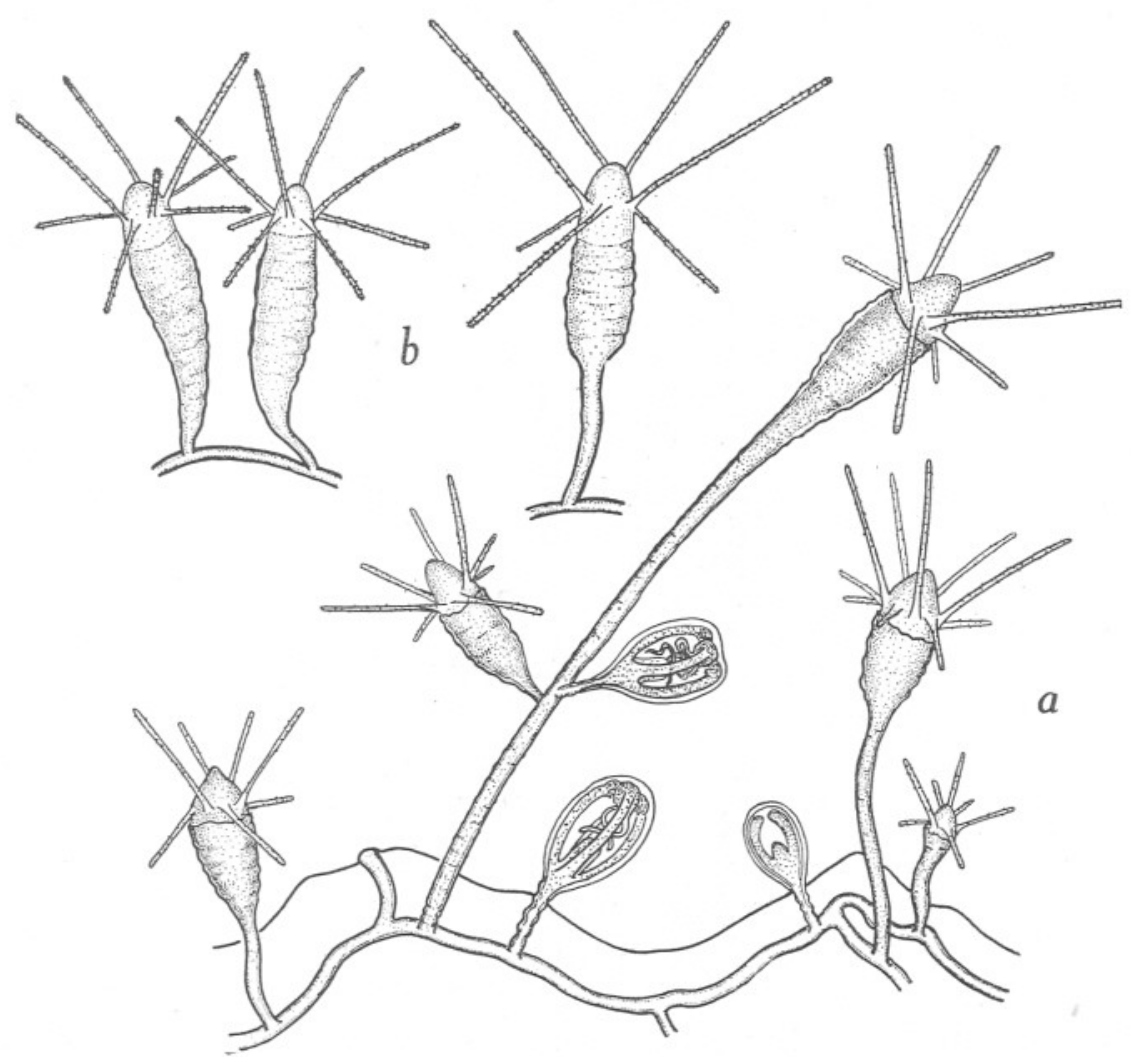

Fig. $4 a, b$. Leuckartiara octona: $a$, hydroid colony growing on a Turritella shell inhabited by a hermit crab; $b$, transitional polyps on the same Turritella shell; Plymouth, r6. iii. 36.

borne on the hydrocauli and only rarely on the stolons. A single hydrocaulus may have one to three medusa buds.

Specimens of Corystes cassivelaunus found at Plymouth frequently carry well-developed colonies which cover the sides of the carapace, the underside and the walking legs. The following description is based on a colony caught in Cawsand Bay on June 29 I937. The hydroid had a tufted appearance, the hydranths appeared white and the stems brownish or horn coloured (Fig. 5). The stolons were $0.05-0.07 \mathrm{~mm}$. in diameter and formed an open network with well-developed branched stems arising at frequent intervals 
from it. The stems were branched three or four times, rising to a height of $2.5-3.0 \mathrm{~mm}$. At their point of origin the stems were annulated having 2-6 annulations, and at this point having a diameter of $0.06-0.08 \mathrm{~mm}$. Above, the stems were slightly and irregularly wrinkled but never annulated. The perisarc widens below the hydranth to form a cup-shaped or funnel-shaped pseudohydrotheca which was much wrinkled. The pseudohydrothecae were $0.4-0.45 \mathrm{~mm}$. in length and $0.2 \mathrm{I}-0.3 \mathrm{~mm}$. in diameter; they reached as far as the base of the

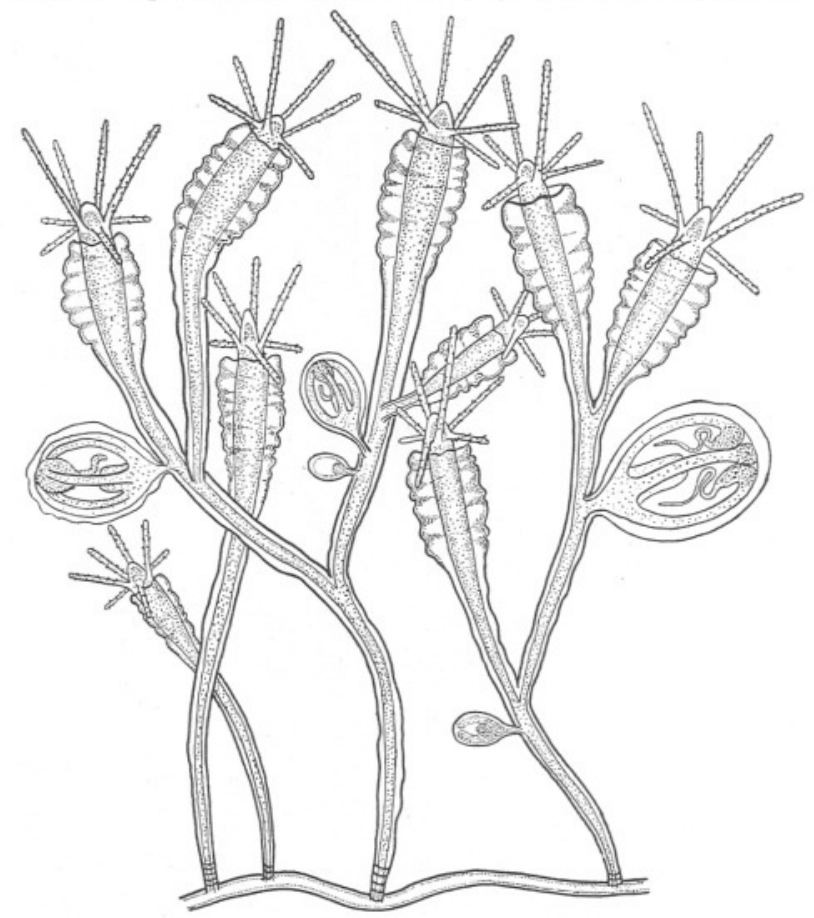

Fig. 5. Leuckartiara octona; well-developed colony on Corystes cassivelaunus; Plymouth, 29. vi. 37.

tentacles. The hydranth itself was spindle-shaped with a distinct hypostome and a whorl of 8-1o tentacles held rather stiffly. Sometimes the tentacles were alternately elevated and depressed. The total length of the hydranth from the base of the pseudohydrotheca to the hypostome was $0.5-0.6 \mathrm{~mm}$. The hydranths and the upper part of the stems were covered by adhering particles of mud. The pseudohydrothecae were slightly gelatinous and mud particles stuck to them very easily.

Medusa buds were borne at all levels on the hydrocauli, but very few were seen developing from the hydrorhiza. There were never more than four medusa buds on the same hydrocaulus. The stalks of the medusa buds were short, and the largest buds seen had a diameter of $0.3-0.35 \mathrm{~mm}$. and a length of $0.35-$ $0.45 \mathrm{~mm}$. 
Mr A. J. Smith found a colony of this hydroid growing on a fish, Agonus cataphractus, captured in the Cattewater, Plymouth, in February I9Io. The hydroid covered portions of the back, fins and the under side of the fish with a luxuriant growth. The stems arose from a creeping network of anastomosing stolons $0.05 \mathrm{~mm}$. in diameter. The stems were usually unbranched, but occasionally stems bearing two hydranths were found. The perisarc was thin, rarely ringed at the base and formed a loose sheath covering the lower part of the hydranth as far as the base of the tentacles. The hydranths were spindle-shaped with six to ten tentacles. Medusa buds were very numerous and were borne on both stems and stolons on distinct stalks with an irregularly wrinkled perisarc. The stems bore from one to four medusa buds. The table below gives measurements of fully developed hydranths and fully developed. medusa buds.

\begin{tabular}{|c|c|c|c|}
\hline \multicolumn{4}{|c|}{ Measurements in $\mathrm{mm}$} \\
\hline eight (to hypostome) & $\cdots$ & & $3 \cdot 8$ \\
\hline of hydranths ... & $\cdots$ & $\cdots$ & $0.65-0.7$ \\
\hline iameter of hydranths & $\ldots$ & $\ldots$ & $0.25-0.3$ \\
\hline er of hydrocaulus & $\ldots$ & $\cdots$ & $0.08-0.12$ \\
\hline of medusa buds & $\ldots$ & $\cdots$ & $0 \cdot 6$ \\
\hline $\mathrm{r}$ of medusa buds & $\ldots$ & $\cdots$ & $0.45-0.5$ \\
\hline & uds & $\cdots$ & $0.1-0.3$ \\
\hline alk of medu & buds & $\cdots$ & 0.05 \\
\hline
\end{tabular}

In appearance this colony compares favourably with the figure of Perigonimus pugetensis Heath I9IO, also found on a fish. Hartlaub (I9I4) doubted whether this species was distinct from $P$. repens.

Discussion. The great variability shown by this hydroid in its mode of growth probably depends largely on the nature of the host and on the substratum on which the host lives.

The creeping form on the shells of living Turritella communis may be a juvenile form, but, as the colonies have medusa buds at the right season, it is more likely that this creeping form is an adaptation to life on a shell which is nearly always buried in mud. The shell is dragged along by the snail and probably frequently rolls over so that no one surface is free from friction. The hydranths remain almost sessile because the depressions on the shell afford them some measure of protection. It was this form which Wright (I857) described as Eudendrium sessile.

Colonies living on the opercula of Turritella shells have much more protection, and they have an erect hydrocaulus which may be branched. Colonies on the "upper side" of shells of this species inhabited by hermit crabs also develop an upright branched hydrocaulus (Fig. $3 c$ ). The shells inhabited by hermit crabs are much more stable, and the polyps on the "upper side" have the opportunity to grow up into branched colonies while the lower side still has the creeping form (Fig. $3 \mathrm{c}$ ). Intermediate polyps between the branched form and the creeping form are frequently found on shells of Nassarius 
reticulatus. The strong branched growth found on Corystes and other crabs will be discussed below.

The perisarc, especially the pseudohydrotheca, is subject to great variation which may possibly be influenced by the kind of food that the colony is able to obtain. Polyps of the creeping form on Turritella shells probably feed on micro-organisms in the mud, so that the coelenteron of each polyp is never dilated by big food masses and so remains as a close-fitting sheath on the hydranth. However, the colonies on the opercula and on the shells inhabited by hermit crabs are moved about more quickly and therefore have a better chance of gorging themselves. The polyps on the shell of the hermit crab may also catch some of the pieces of an animal caught by the hermit crab. This would cause the hydranth and its pseudohydrotheca to become considerably distended. After the digestion of the food the hydranth would shrink to its normal size leaving the perisarc as a loose-fitting sheath. A slight shrinking of the latter would result in the irregular wrinkling so typical of the pseudohydrothecae of well-developed colonies. The colonies on crabs are subject to more movement than those on shells and may receive larger particles of food from the host so that the pseudohydrothecae are largest in these colonies. The perisarc was thickest and more strongly developed in colonies from Corystes and other crabs. It was sometimes ringed at the base, but this character was very variable. When newly formed the perisarc was thin and transparent. The colony figured by Allman (1872) as Perigonimus minutus appears to me to be a young colony of this species.

In all my living specimens the pseudohydrothecae never extended beyond the base of the tentacles, but in some preserved specimens the contraction of the hydranth made it appear that the hydranth was largely retractile. P. vestitus Allman I864 $b$ has been regarded by Hartlaub (I9I4) and Kramp (I927) as synonymous with this species. Moreover, $P$. vestitus has, according to Allman's text and figure, a continuation of the perisarc beyond the base of the tentacles as a thin transparent membrane which is continued almost as far as the mouth. It must, therefore, be retained as a separate species. Stechow (1923) has placed this species in the medusa genus Cytaeis as C. vestita, although Allman's figure clearly shows that this medusa is a typical pandeid.

The position of the gonophores on the hydrocaulus and on the stolon, together with the branched and sessile hydranths in his two forms, led Wright to regard his Eudendrium pusillum and his E. sessile as two distinct species. Medusae have been reared in the Plymouth Laboratory which leaves no doubt that $E$. sessile is identical with the branched form.

The hydroid, as has already been stated, grows on a wide range of animals. Stechow (1929) found this species growing on the under side and between the parapodia of Aphrodite aculeata. It has not yet been recorded from this species at Plymouth.

The hydroid and medusa seem to have a cosmopolitan distribution. The hydroid has been recorded from Arctic seas by Kramp (1938), from the Pacific 
coast of North America by Calkins (I899), Torrey (1902) and Fraser (1937), from South America by Stechow (I9I9) and from the Indian Ocean by Leloup (1932), to mention only a few of the records.

The synonyms of the hydroid are given below:

\section{Leuckartiara octona (Flemming, I823)}

Hydroid synonyms: Eudendrium pusillum Wright 1857 ; E. sessile Wright I857; E. repens Wright I858; Atractylis repens Wright I858; A. sessilis Wright I858; Perigonimus minutus Allman 1863; P. sessilis Allman I864; P. pusillus Allman 1864; Dinema slabberi van Beneden I866; ? Perigonimus pugetensis Heath I9IO; Leuckartiara pusilla Stechow 1929.

\section{Leuckartiara abyssi (G. O. Sars, I873)}

\section{Synonym: Perigonimus abyssi G. O. Sars.}

This small species was found living on the shells of Nucula timidula at Herdla. It was originally described by G. O. Sars (I873) from Hitvingsø, growing on shells of living Dentalium at depths varying from 80 to 200 fathoms, and also on shells of Nucula timidula from the Hardangerfjord down to 400 fathoms. Since then there have been numerous records from Scandinavian seas (for details see Jäderholm, I909; Ritchie, I913; and Broch, I9I6). It has also been reported from Greenland by Kramp (I9II), as Perigonimus sp. by Broch (I9I6), and from Spitzbergen by Broch (I909) from very shallow water. The only British record is that of Ritchie (I9I3), who records it from the Atlantic off south-west Ireland at a depth of 900 fathoms on Nuculana pustulosa.

Bonnevie (1899), in her report on the Hydroida of the Norwegian North Atlantic Expedition, states that the gonophores "probably develop into free medusae", but in her table of species she states that the gonosome is a freeswimming medusa with four radial canals and four tentacles. I can find no reference to this in literature previous to 1899 , but all later authors have apparently quoted Bonnevie with respect to the medusa (Broch, I9I6; Kramp, 1935).

Sars (I873) and Jäderholm (1909)* are the only authors who have figured this species with medusa buds, but their figures and descriptions are from preserved material. There is no published figure of the liberated medusa. I have therefore thought it desirable to redescribe the species in detail from living material.

Colonies of this hydroid were obtained from two localities at Herdla. Three colonies on Nucula timidula were obtained from a depth of $100-200 \mathrm{~m}$. in the Herdlafjord on July 3I 1937 by Dr Hult in his "sledge dredge". Dr Hult kindly gave me these colonies for examination, of which two had each a single gonophore. On August 6 1937, about a hundred Nucula timidula were obtained by the same apparatus in the Hjeltef jord, south of Toska at a depth

\footnotetext{
* The hydroid figured by Jäderholm may be a different species.
} 
of $300-400 \mathrm{~m}$. Twelve of these molluscs had colonies growing on them, but only three colonies carried gonophores.

The stolons form an open network on the surface of the valves of the shell (Fig. $6 \mathrm{a}$ ). They are of a light brown colour and $0.05-0.07 \mathrm{~mm}$. in diameter. The stems are unbranched rising to a maximum height (to top of hypostome) of

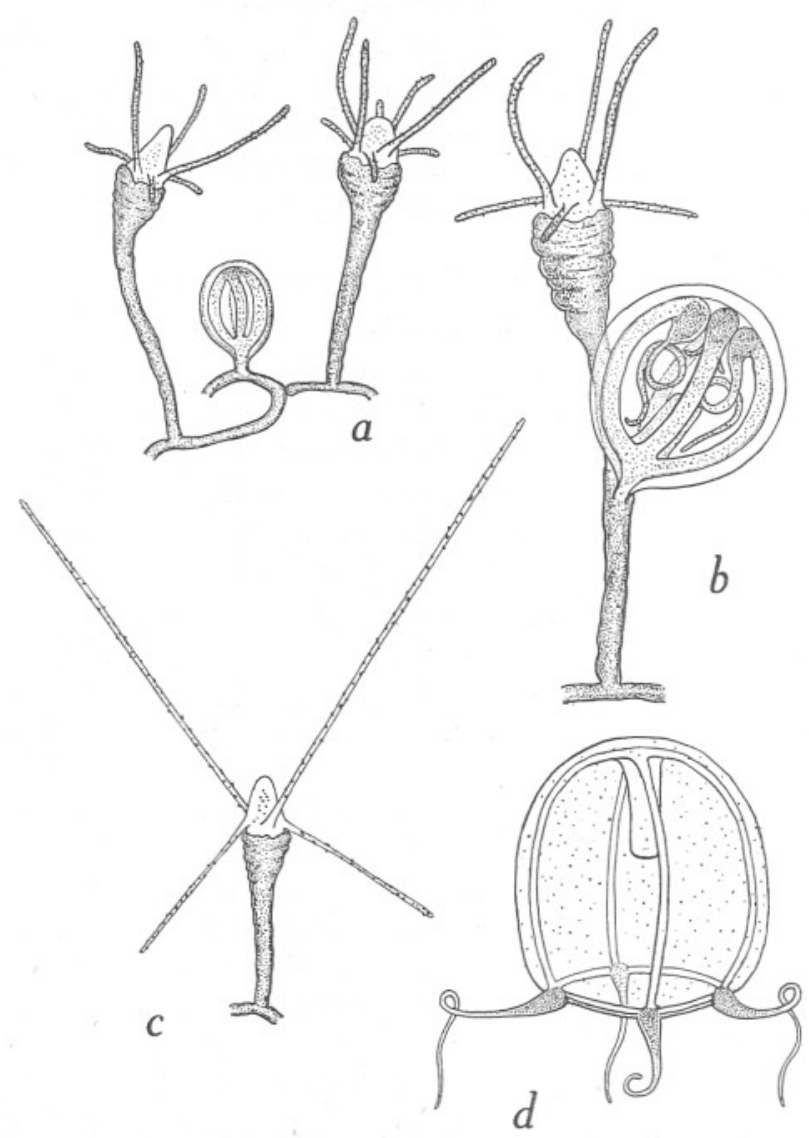

Fig. $6 a-d$. Leuckartiara abyssi (G. O. Sars): a, portion of colony with a gonophore developing from the stolon, Herdla, 6. viii. $37 ; b$, polyp with a fully developed gonophore on the hydrocaulus, Herdla, 9 . viii. $37 ; c$, young polyp with its tentacles fully expanded, Herdla, 6 . ix. $37 ; d$, newly liberated medusa.

I. I $\mathrm{mm}$. and are covered by a dark brown or horn-coloured perisarc with adhering mud particles. The perisarc of both hydranth and hydrocaulus is often irregularly wrinkled throughout, but never ringed at the base. It becomes dilated around the base of the hydranth to form a pseudohydrotheca, reaching almost to the base of the tentacles where it thins out and disappears. Too much stress has been laid by some authors on the wrinkling of the perisarc, distinguishing the species by this means from the hydroid of Leuckartiara octona (Fleming). 
Either the very pronounced wrinkling shown in Jäderholm's figure is due to bad fixation or the species figured is distinct from Sars' species. A comparison of Fig. $6 a-c$ with those of the hydroid Leuckartiara octona (Figs. 3-5) reveals that the wrinkling of the perisarc cannot be used as a specific character to distinguish the two species.

The hydranth is fusiform or flask-shaped, with a well-developed conical hypostome and a whorl of six to eight filiform tentacles held fairly stiffly, alternately elevated and depressed, the longer tentacles held almost vertical and the shorter ones almost at right angles to the hydrocaulus. Frequently the whole hydranth is so covered with mud particles that only the white tip of the hypostome and the ends of the tentacles can be seen.

The limits of hydranth and hydrocaulus are not clearly marked, the transition being gradual. When extended the tentacles are very thin and the nematocysts appear to be scattered irregularly on them. The fully extended tentacles may reach a length of $\mathrm{I} \cdot 2 \mathrm{~mm}$. (Fig. $6 \mathrm{c}$ ).

Only three living colonies with gonophores were found, and in each there was only one developing gonophore. ${ }^{\star}$ Sars (I873) also noted that few colonies had gonophores and that in these the gonophores were particularly few.

In two of the colonies the bud was developing from the stolon (Fig. $6 a$ ) and in the third from the hydrocaulus. The gonophore developing from the hydrocaulus was in an advanced stage of development (Fig. $6 \mathrm{~b}$ ) when found on August 6 I937. The young medusa bud was covered by a thin hyaline perisarc and was $0.45 \mathrm{~mm}$. long by $0.45 \mathrm{~mm}$. in diameter. It had a very short stalk $0.05 \mathrm{~mm}$. in length. Three days later it had grown to $0.5 \mathrm{~mm}$. long by $0.45 \mathrm{~mm}$. in diameter. The bud was liberated as a free medusa on the same day by rupture of the perisarc.

The newly liberated medusa (Fig. $6 d$ ) was of a deep bell shape, $\mathrm{I} \cdot \mathrm{I} 5 \mathrm{~mm}$. in height and $\mathrm{I} .05 \mathrm{~mm}$. in diameter. It had a fairly thin jelly of uniform thickness with no apical projection. Numerous nematocysts were scattered in the surface of the exumbrella. The velum was present. The stomach was short, quadrangular in section, reaching to about one-third the height of the umbrella cavity. The mouth was simple without distinct lips. The four radial canals and ring canal were fairly broad. There were four perradial tentacles with elongated hollow conical bulbs; of these, two opposite tentacles were better developed than the other two. There were no ocelli, and the colour of the tentacle bulbs and manubrium was a pale yellowish green.

The structure of the newly liberated medusa clearly shows that it belongs to the family Pandeidae. The hydroid appears to be very closely related to the hydroid of Leuckartiara octona (Fleming) (=Perigonimus repens (Wright, I857)). The structure of the newly liberated medusa, however, shows it to be quite distinct from this species. The medusa differs from that of Leuckartiara octona in having partly developed tentacles on the two smaller perradial bulbs; it is much larger and more globular, there is no apical projection, and the

\footnotetext{
* Dr Hult's specimens were already fixed when handed over to me.
} 
colour is distinct. The species may be the hydroid generation of another species of Leuckartiara or possibly Neoturris pileata (Forskål). Provisionally at least it appears best to place this species in the medusa genus Leuckartiara, as the generic name Perigonimus can no longer be used for the hydroids of pandeid medusae. The name of this species therefore becomes provisionally Leuckartiara abyssi (G. O. Sars, I873).

\section{Thamnostoma russelli n.sp.}

A small hydroid closely resembling Thamnitis cidaritis ${ }^{\star}$ (Weismann I883) was caught in the Mielck net in the Herdlafjord at a depth of $270 \mathrm{~m}$. on August 3I 1937. The species carried medusa buds and in nearly all respects appeared to be almost identical with Weismann's species from the Mediterranean. The structure of the newly liberated medusa, which differed in several respects from that of $T$. cidaritis, indicated that the species can probably be regarded as distinct.

The species described below is a form of some importance in that the structure of its medusa indicates that two medusa genera, at present kept separate, should be united under one genus.

THE HYDROID. The species was a mud-living form anchored in the mud by a twisted network of branching stolons (Fig. 7 a). When found the colony was covered with mud with only the tips of the tentacles and the hypostomes of the hydranths visible. The stolons were thin, being $0.05 \mathrm{~mm}$. in diameter. The perisarc of the stolons, the hydrocauli and the hydranths, was of a brownish colour and non-annulated. The polyp stems were unbranched and $2-5 \mathrm{~mm}$. in length with a diameter of $0.10-0.12 \mathrm{~mm}$. They were usually irregularly bent and only occasionally straight.

The hydranths (Fig. 7 b) were fusiform, $0.3-0.5 \mathrm{~mm}$. in length and $0.25-$ $0.4 \mathrm{~mm}$. in diameter. They had a single whorl of ten to fifteen filiform tentacles around a conical hypostome. The hydranths were covered by a loose irregularly wrinkled perisarc, which was continued over the body of the hydranth to within a short distance of the mouth and formed a sheath on the proximal portion of each tentacle. This tubular sheath was $0.03 \mathrm{~mm}$. in diameter. The distal end of the tentacle was club-shaped with numerous nematocysts at the tip forming a battery. Each tentacle had an endodermal core consisting of a single row of cells.

The stems carried one, two or three medusa buds on very thin stalks $0.3-$ $0.35 \mathrm{~mm}$. long. Fully grown medusa buds were $0.5-0.55 \mathrm{~mm}$. in length with a diameter of $0.5 \mathrm{~mm}$. The gonophore was covered by a very thin perisarc which was ruptured when the young medusa was liberated.

The Medusa. The newly liberated medusa had a height of $\mathrm{I} \cdot 2-\mathrm{I} \cdot 6 \mathrm{~mm}$.

* This species was described by Weismann as Perigonimus cidaritis. Brückner (I9I4) redescribed both hydroid and medusa and gave the medusa the name Thamnitis dichotoma. Stechow (1919) referred the hydroid to Thamnitis cidaritis as the species is clearly not a Perigonimus. 
and a diameter of $\mathrm{I} \cdot 2-\mathrm{I} \cdot 35 \mathrm{~mm}$. (Fig. $7 \mathrm{c}$ ). The umbrella was deep bell-shaped, a little higher than wide, with a thin jelly of fairly uniform thickness. There

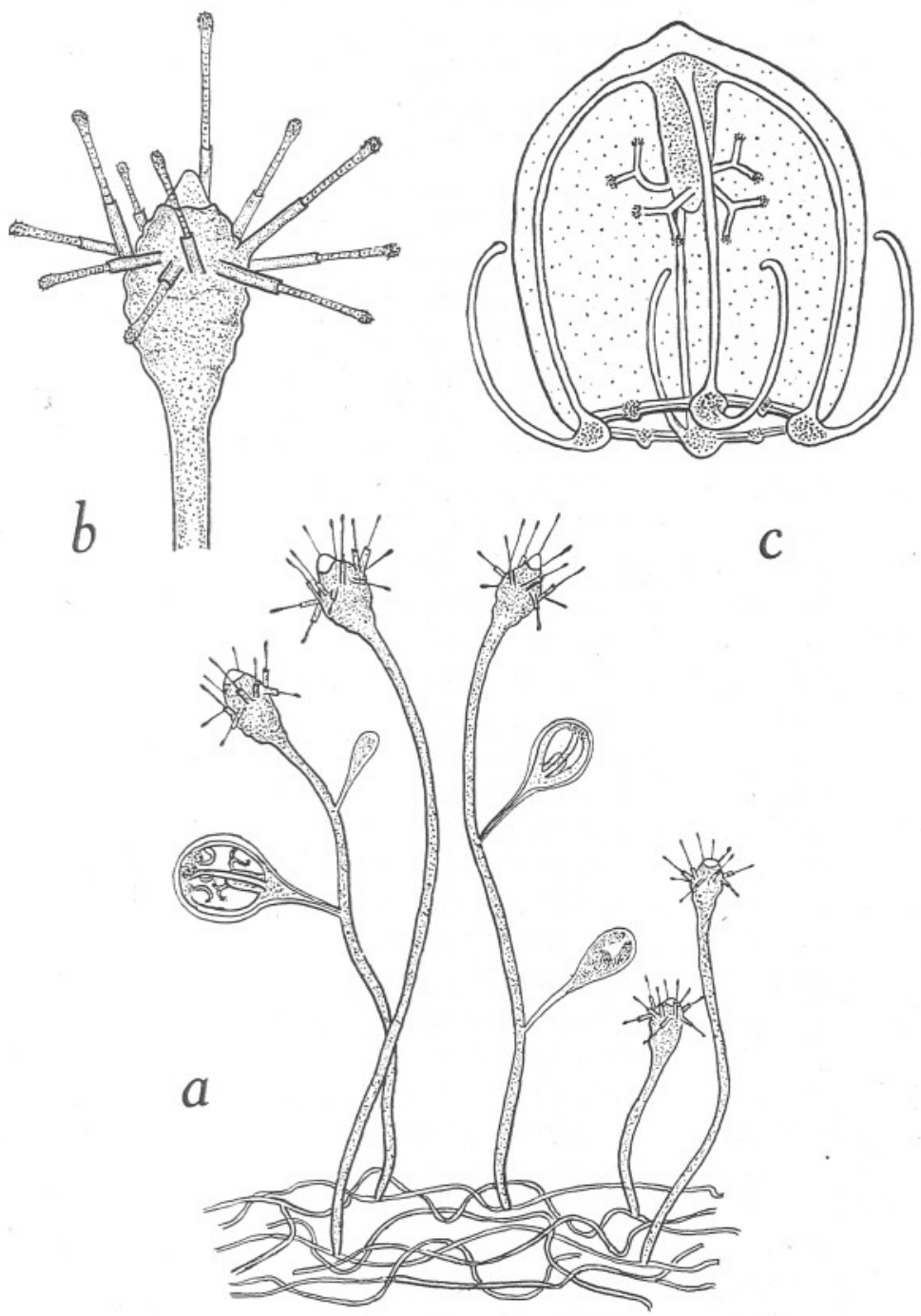

Fig. $7 a-c$. Thamnostoma russelli n.sp.: $a$, colony with medusa buds, Herdla, 6. ix. 37; $b$, single hydranth, Herdla, I. ix. $37 ; c$, newly liberated medusa, Herdla, 2. ix. 37 .

was a slight apical projection, and here the jelly was a little thicker than elsewhere. There were a large number of nematocysts scattered over the surface of the exumbrella. The stomach was short, cylindrical and reached to almost one-third of the height of the subumbrella. The mouth was simple with four 
branched oral tentacles arising from the manubrium a little above the mouth. Each oral tentacle divided once, each arm having a small battery of nematocysts at its distal end. The radial canals and the ring canal were narrow. There were four well-developed perradial bulbs each with a tentacle and four interradial smaller bulbs without tentacles. There were no ocelli. The tentacle bulbs were yellowish brown in colour, and the base of the stomach was green and its tip reddish brown.

After three days' growth in the laboratory a medusa developed four short interradial tentacles, and the oral tentacles on the manubrium were beginning to branch a second time. The development was not studied further.

This species from Norway is evidently closely related to the Mediterranean species Thamnitis cidaritis. The hydroids appear to be almost indistinguishable, but the medusae differ in several respects. Brückner (1914) referred the medusa of the Mediterranean species to the genus Thamnitis as T. dichotoma on account of the presence of the branched oral tentacles and the four single perradial tentacles. His species differs from my species principally in the absence of interradial bulbs, in its smaller size, and also in the better development of the capitate knobs on the oral tentacles.

Browne (1905) found two small medusae in the Firth of Clyde, Scotland, which he referred to Thamnitis as Thamnitis sp. Except for the absence of interradial bulbs they appear to be almost identical with my species. The medusa of my hydroid is also related to the medusa Thamnostoma dibolia (Busch I85I) from the Gulf of Trieste. This species is only known in the adult stage and nothing is known of its hydroid. It possesses a peculiar spur on the tentacles, and the tentacles also possess ocelli.

It is possible that Thamnostoma dibolia and Thamnitis cidaritis are stages in the life history of the same species. If this proves to be so then the question whether my species is distinct from $T$. cidaritis will have to be considered. It appears possible that in warm waters the medusae are liberated at an earlier stage of development at which the interradial bulbs have not been developed. For the present it is necessary to keep my species distinct. The close similarity between the hydroid of my species and that of $T$. cidaritis, and the fact that the medusa has more than four tentacles, indicate that the retention of both the generic names Thamnitis and Thamnostoma is no longer justified. Mayer (I9I0) placed all the species previously assigned to Thamnostoma in the genus Lymnorea Péron \& Lesueur I809. Hartlaub (I9II) has shown that Mayer draws no distinction between branched oral lips and branched oral tentacles, and he therefore restricts Lymnorea to medusae of the Podocoryne type with branched oral lips and numerous marginal tentacles.

Haeckel (1879) placed his genera Thamnitis and Thamnostoma in his family Thamnostomidae with T. dibolia as the genotype of his genus Thamnostoma.

Thamnostoma is redefined as follows to include Thamnitis:

MEDUSA. Thamnostomid medusae with four or more marginal tentacles and four branched oral tentacles above the mouth. 
HYDROID (where known). Stems rarely branched arising from a creeping stolon both covered by a brownish perisarc. Hydranths fusiform, with a single whorl of filiform tentacles around a conical hypostome, covered almost as far as the mouth by an investing perisarc which also forms a sheath around the base of each tentacle. Medusa buds, stalked, borne on the hydrocauli. *

The following species, Thamnostoma dibolia (Busch I85I), T. macrostoma Haeckel I879, Thamnitis tetrella Haeckel I879, T. cidaritis (Weismann I883) and Thamnitis sp. Browne 1905 can be referred to this genus. To these we must add the new species described above, which I propose to call Thamnostoma russelli after Mr F. S. Russell.

The following is a concise definition of this new species:

\section{Thamnostoma russelli $\mathrm{n} . \mathrm{sp}$. (Fig. 7)}

Stem slender, unbranched, rooted by a tufted mass of thread-like stolons, the whole of the coenosarc enclosed in a brownish non-annulated perisarc; hydranths fusiform, with a single whorl of ten to fifteen filiform tentacles around a conical hypostome, the body and the lower half of each tentacle clothed in a thin perisarc which is irregularly wrinkled on the body of the hydranth. Gonophores medusoid, borne on very slender pedicels on the hydrocauli. Medusa (at liberation) bell shaped, jelly thin, with numerous scattered exumbrellar nematocysts. Umbrella with a slight apical projection. Velum present. Stomach short, cylindrical, with a simple mouth with four dichotomously branched oral tentacles arising above mouth margin. Four radial canals and ring canal narrow. Four perradial marginal tentacles with enlarged basal bulbs and four interradial bulbs with developing tentacles. Tentacular bulbs brownish, stomach green at base, reddish brown distally.

Distribution: Bergen coast (Herdlafjord).

\section{The HydroId OF EUPHYSA AURATA Forbes I848}

Many specimens of the mud-living hydroid Corymorpha annulicornis $M$. Sars I859 were obtained at Herdla, and from them young specimens of the medusa Euphysa aurata Forbes were liberated. Until recently the hydroid Corymorpha nana Alder I859 has been almost universally accepted as the hydroid of this medusa (e.g. Kramp, I927; Mayer, I9I0). Browne (I896), alone of modern authors, was convinced that it was not the right hydroid of this medusa. The description given by Alder for $C$. nana differs in so many respects from that of $C$. annulicornis that they cannot possibly be the same species. The newly liberated medusae, however, are rather similar, and the medusa of C. nana may prove to be another species of Euphysa.

* There is a close similarity between these two hydroids and Bimeria vestita Wright 1859 which has fixed gonophores. It is premature at present to place these species in Bimeria. This genus has been united with Garveia Wright, which has no tubular perisarc sheaths covering the tentacles of the hydranth, by some authors, e.g. Torrey (I902), Browne (I907), and Stechow (I919), while others, e.g. Fraser (1937), have kept them separate. A revision of the BimeriaGarveia hydroids is greatly to be desired. 
Although the figures of both hydroid and medusa are by no means typical, the hydroid, described by E. S. Russell (1906) as Trichoriza brunnea (Rhizo-

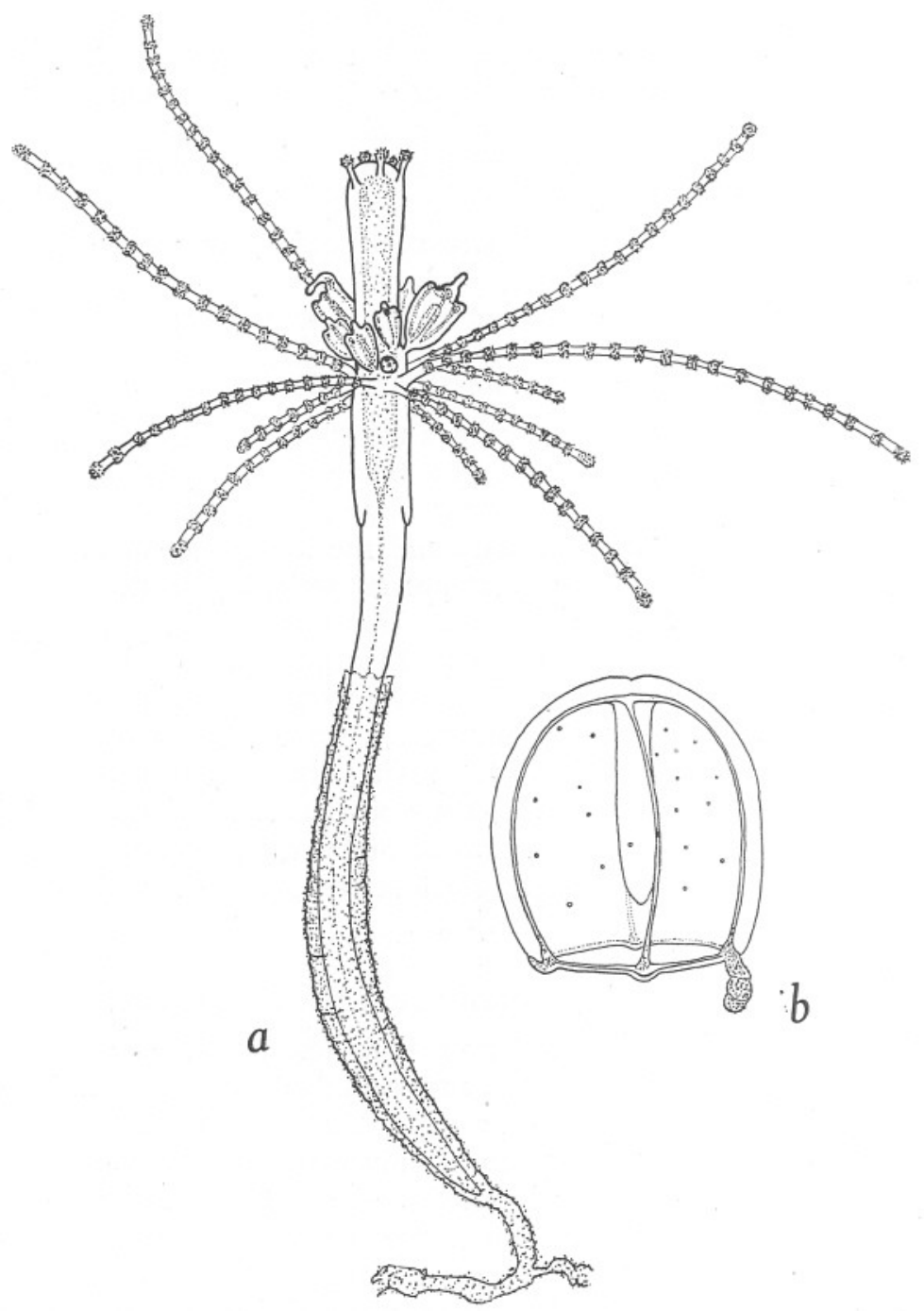

Fig. $8 a, b$. Corymorpha annulicornis M. Sars: $a$, expanded polyp with medusa buds, Herdla, I2. viii. $37 ; b$, young medusa newly liberated from the hydroid, Herdla, II. viii. 37 .

trichia of Stechow, 1919), is undoubtedly identical with Corymorpha annulicornis.

Having seen young specimens of $C$. annulicornis alive at Herdla I have now no hesitation in referring the specimens I described from Plymouth (Rees, 1937) as Heterostephanus sp. to this species. 
Dahlgrenella farcta Miles I937 is very closely related if not identical with Corymorpha annulicornis. The validity of the genus Dahlgrenella will be discussed later in this paper.

The hydroids were obtained at Herdla with a similar "mud-tangle" apparatus to that described by Miles (I937). The list of localities where the hydroid was found is given below:

9. viii. 37. Ypsøsund, 70 m., II specimens.

9. viii. 37. Iø, $20 \mathrm{~m} ., 3$ specimens.

9. viii. 37. Rosslandspollen, $30-40 \mathrm{~m}$., 4 specimens.

9. viii. 37. Herdlafjord, I00 m., 2 specimens.

I4. viii. 37. Mangerfjord, $200-300 \mathrm{~m}$., I specimen.

18. viii. 37. Ypsøsund, $70 \mathrm{~m} ., 33$ specimens.

4. ix. 37. Ypsøsund, $70 \mathrm{~m}$., I2 specimens.

The two specimens from the Herdlafjord were obtained by Dr Hult in his "sledge dredge", and the single specimen from the Mangerfjord by washing and sieving the mud from the upper part of the trawl netting. All the other specimens were obtained by dragging the "mud-tangle" along the bottom for $20 \mathrm{~min}$. Each record represents a single haul.

Of all the specimens obtained about 50 per cent carried medusa buds, about Io per cent were fully grown without buds, and the remainder were young polyps.

Five young hydroids of this species were obtained from Jennycliff Bay, Plymouth Sound, on September 27 I937.

THE HYDROID. The stems are unbranched consisting of a claviform or clubshaped head and a tubular hydrocaulus (Figs. 8, 9). The limits of the hydranth and the stalk are not always clearly marked; in some specimens the head merges imperceptibly into the stalk. The head varies greatly in shape and carries two whorls of tentacles. Some idea of the variation in number of the tentacles and in the size of the medusa-bearing polyps can be obtained from the following table. The measurements are from specimens fixed in Bouin's fluid. When alive the polyps can expand to four or five times the length of the contracted state:

\section{Measurements in $\mathrm{mm}$.}

$\begin{array}{lcccl}\text { Total length } \ldots & \ldots & \ldots & \ldots & \text { I.I5-4.55 } \\ \text { Length of head... } & \ldots & \ldots & \ldots & 0.6-\mathrm{I} \cdot 8 \\ \text { Diameter of head } & \ldots & \ldots & \ldots & 0.35-0.9 \\ \text { Length of hydrocaulus } & \ldots & \ldots & 0.15-\mathrm{I} \cdot 8 \\ \text { Diameter of hydrocaulus } & \ldots & \ldots & 0.2-0.5 \\ \text { Number of oral tentacles } & \ldots & \ldots & 3-8 \\ \text { Number of aboral tentacles } & \ldots & \ldots & 6-14 \\ \text { Number of medusa buds } & \ldots & \ldots & \text { I-27 }\end{array}$

The oral tentacles are capitate and generally four in number. The aboral tentacles are moniliform, situated near the posterior end of the hydranth; their usual number is eight to ten. 
The aboral tentacles consist of longer and shorter tentacles which alternate and appear to be in two closely approximated whorls, the longer tentacles always arising a little in front of the shorter tentacles. This can only be seen in fully developed individuals. In full-grown polyps bearing medusa buds the

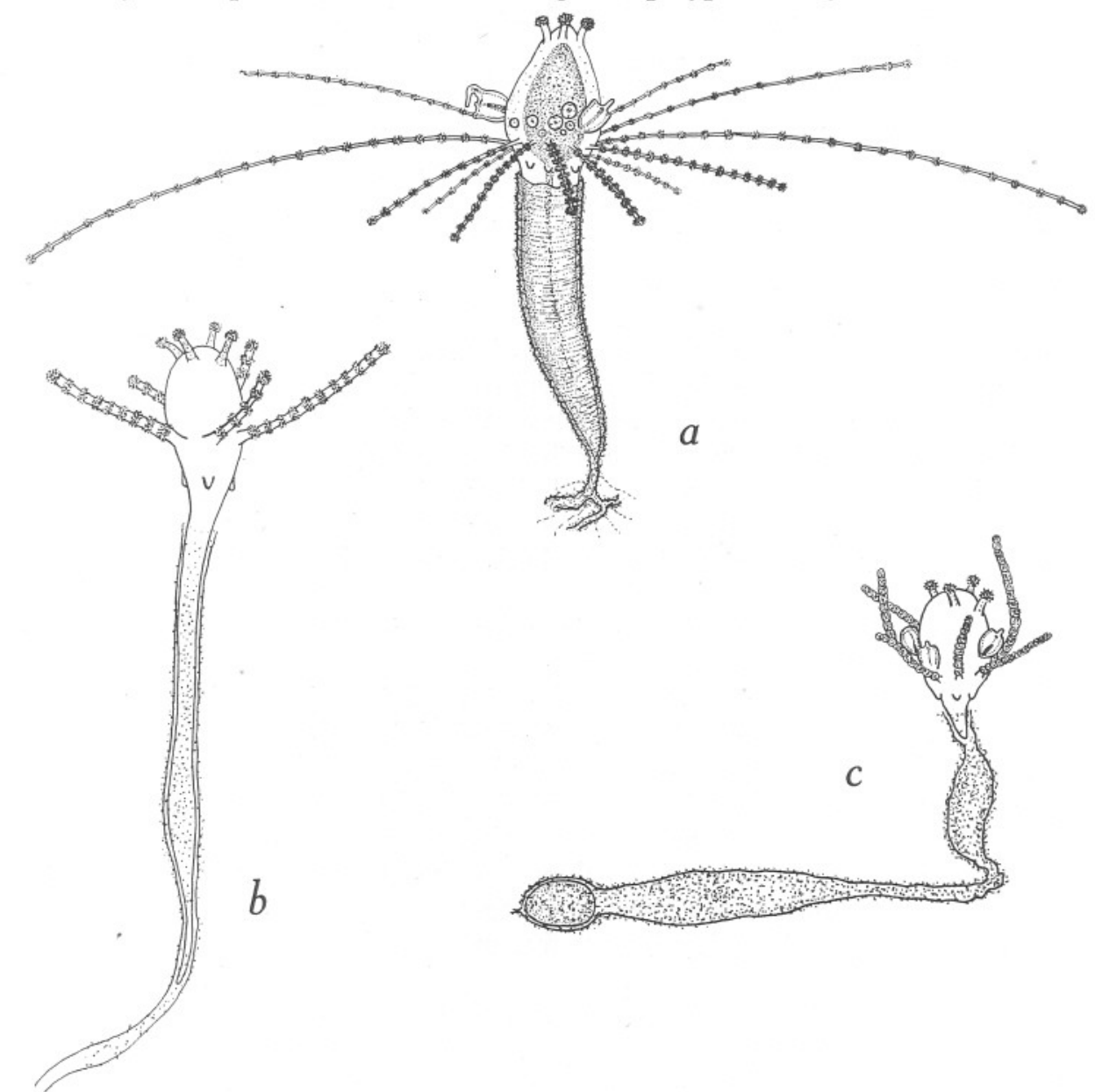

Fig. $9 a-c$. Corymorpha annulicornis M. Sars: $a$, polyp with medusa buds, body contracted, tentacles expanded, Herdla, 1o. viii. $37 ; b$, young polyp developed by asexual budding from the stolon, Herdla, 9 . viii. $37 ; c$, polyp with an asexual body in the stolon, Herdla, 4. ix. 37 .

number of annulations on each aboral tentacle varies from six to twenty-five. At the posterior end of the hydranth there is a whorl of three to six backwardly directed papillae, and there are also occasionally some on the upper part of the hydrocaulus. One individual had three of these processes, and three other polyps had one each. Similar processes are found scattered on the upper part of the 
hydrocaulus of Dahlgrenella farcta; according to Miles (1937) they develop into anchoring filaments, but I saw no indication of this in my specimens. The original specimens taken by Sars near Bergen seem to have been much larger than mine from the same district. His polyps possessed eight to ten oral tentacles, about twenty aboral tentacles and six to eight backwardly directed papillae.

The simple hydrocaulus is covered by a distinct slightly gelatinous membrane which covers the greater part of the hydrocaulus. When the hydrocaulus is expanded the membrane forms a smooth loose-fitting sheath reaching twothirds of the way up the hydrocaulus; when the hydrocaulus is contracted the membrane contracts with it and appears to be transversely wrinkled. It is almost always covered with fine particles of mud which adhere to it. Below the base of the hydrocaulus the tube may narrow abruptly to form an irregularly branched or unbranched stolon which serves as an anchoring filament. In specimens which have been kept alive in small glass dishes, very thin hair-like anchoring filaments or frustules frequently appear from the posterior fourth of the hydrocaulus and fix the animal securely to the substratum. In the specimens I kept there were never more than ten of these filaments.

Among the eleven specimens obtained from Ypsøsund on August 91937 there was one polyp with an asexual bud developing from the body of the hydranth. It was a reversed bud similar to the one described (Rees, I937) for this species from Plymouth. In this instance no tentacle of the parent polyp was carried away by the bud, which had four oral and four aboral rudiments of tentacles. As in the Plymouth specimen the parent polyp was immature and without gonophores.

The development of young polyps from the stolon is common in this hydroid, and for this Ypsøsund proved to be the most interesting station. Such buds have been described by Broch (1937) for Corymorpha annulicornis and by Miles (1937) for Dahlgrenella farcta. ${ }^{\star}$ Broch notes the presence of a rounded body in the stolon below the hydrocaulus and suggests that it may be a schizospore. In the material from Ypsøsund (September 4 I937) there are several such bodies in the periderm of different polyps. In one the lower part of the hydrocaulus was becoming constricted off (cf. D. farcta); in another the proximal end of the periderm contained a rounded body (Fig. 9 c). It has already been mentioned that a large percentage of the polyps found were very young ones.

Few, however, of these young polyps were attached by their stolons to the parent polyps, and it is very probable that, in the process of washing and straining the mud, the thin periderm, connecting most of them to their parent polyps, becomes severed.

The youngest polyp still attached to its parent polyp by the periderm possessed four oral tentacles, four aboral tentacles and four backwardly directed processes (Fig. 9 ) ).

* Murbach (1899) has also described such buds in Hipolytus peregrinus, a form which approaches nearest to Corymorpha obvoluta Kramp and with which it is almost certainly cogeneric. 
Measurements of this bud (when alive) are given below:

\begin{tabular}{lcccl}
\multicolumn{5}{c}{ Measurements in $\mathrm{mm}}$. \\
Total length $\ldots$ & $\ldots$ & $\ldots$ & $\ldots$ & \multicolumn{1}{l}{ I. 75} \\
Length of head & $\ldots$ & $\ldots$ & $\ldots$ & 0.65 \\
Diameter of head $\ldots$ & $\ldots$ & $\ldots$ & 0.32 \\
Length of hydrocaulus & $\ldots$ & $\ldots$ & I. I \\
Diameter of hydrocaulus & $\ldots$ & $\ldots$ & $0.12-0.2$
\end{tabular}

The oldest bud still attached to its parent by the periderm had seven medusa buds and a proximal whorl of ten tentacles. *

Broch (1937) suggests that the British species of Vorticlava, V. humilis Alder 1856 and $V$. proteus Wright (1863), may possibly be young Corymorpha annulicornis, but I cannot agree with this suggestion. Alder and Wright examined their specimens alive, and it is hardly likely that such careful workers would have missed such a striking feature as the annulation of the tentacles had the tentacles been annulated. It appears more likely that these young forms are larval tubularians as suggested by Brink (1925).

Sexual Reproduction. The medusa buds are borne singly or in groups of two to six just above the aboral whorl of tentacles. It is questionable whether the small protuberances on which these buds are borne can be called blastostyles. Each bud is naked. It arises as a globular swelling which gradually enlarges, becoming bell-shaped. The manubrium and the four radial canals develop, and at the margin of the bell opposite one of these radial canals a small finger-like tentacle is formed (Fig. $8 a$ ). The tentacle as it grows bends inwards like a hook and develops two or three nematocyst batteries. At first its colour is green, but when the medusa is about to be liberated it becomes golden yellow.

When liberated the medusa (Fig. $8 b$ ) is of a deep bell shape; the jelly is uniformly thin and there are a few large scattered nematocysts on the exumbrella. The velum is well developed. The stomach is tubular and well developed; the mouth is simple. The stomach is about two-thirds of the length of the subumbrellar cavity. The four radial canals and the ring canal are narrow. There is only one tentacle; this is short and club-shaped when contracted, when expanded it is moniliform, having two or three nematocyst batteries. The tentacle bulbs on the other perradii are small and rudimentary. Each bulb clasps the margin of the bell.

Newly liberated medusae are when alive $0.55-1.0 \mathrm{~mm}$. in height by $0.55^{-}$ $\mathrm{I} . \mathrm{O} \mathrm{mm}$. in diameter. Individual medusae range from brightly coloured specimens to almost colourless ones. The subumbrella and radial canals are faintly pink in some, in others colourless. In brightly coloured medusae the ring canal

* Since this paper was written I have received from Dr Hult a species of Corymorpha obtained in the Trondheimsfjord from a depth of about $480 \mathrm{~m}$. It approaches very near to and may be identical with $C$. annulicornis. It is much larger than my Herdla specimens, having a total length of $9.5 \mathrm{~mm}$. There are well-developed branched blastostyles bearing gonophores which are distinctly medusoid in form. Without more knowledge of the gonophore, however, I prefer not to refer this specimen to $C$. annulicornis. 
appears as a crimson circle. There is always a crimson pigment spot at the tip of the manubrium, the remainder is yellow, sometimes with brownish pigment at the base. The upper part of the tentacle bulbs including the junction of the radial and ring canals is vivid scarlet or crimson with a few black pigment granules at the ends of the radial canals. The single tentacle is golden yellow in colour and the lower part of the tentacle bulbs which clasp the margin are also yellow.

The newly liberated medusae and the various stages seen in the townets at Herdla confirm Broch's opinion that this species is identical with Euphysa aurata Forbes. The newly liberated medusae (of which one was captured in the townets) correspond to those described by Browne (1896). Browne states that: "The shape of the umbrella, of the tentacle bulbs, and of the large tentacle is similar in all stages: thus there is no difficulty in identifying the earliest forms."

The youngest stage captured in the Herdlafjord on September 2 I937 was obviously a newly liberated specimen and differed in no way from those already described. It was $0.75 \mathrm{~mm}$. in height by $0.7 \mathrm{~mm}$. in diameter.

A slightly older specimen caught in the Hjeltefjord on September 231937 possessed a slightly thicker jelly and a slightly longer tentacle. It was immature and was I.I mm. high and $\mathrm{I} .05 \mathrm{~mm}$. in diameter.

A ripe male medusa was obtained in a haul in the Hjeltefjord south of Toska on September 2I 1937. It only differed from specimens previously described here in its greater size, greater thickness of jelly, length of tentacle and the presence of the gonad on the manubrium. It was $2.5 \mathrm{~mm}$. high by $2.0 \mathrm{~mm}$. in diameter.

Euphysa aurata is the only species of its genus with the same distribution as the hydroid Corymorpha annulicornis. According to Kramp (1927) the medusa occurs from the English Channel to the Murman coast. It has also been reported from Greenland (Kramp, I926) and from the Mediterranean. It is very common along the Scottish coasts and along the Norwegian coast.

The records of the hydroid are few, probably because the species is a mud-living form and necessitates a special apparatus to catch it. Sars (1859) found two species at Flören (Sondfjord) in the Bergen district. Russell (1906) has recorded it from the Firth of Clyde as Trichorhiza brunnea, and the present writer has found it abundant at Herdla (Bergen), and also less commonly at Plymouth.

The only other north European species of Euphysa is E. tentaculata (Linko 1904) which is only known from the Barents Sea and a few localities in the southern Kattegat and the Belt Sea (Kramp, 1927).

It is therefore almost certain that the medusa $E$. aurata can be linked with the hydroid Corymorpha annulicornis.

The species was originally described by Michael Sars (1859) as C. ? annulicornis: Sars himself was doubtful which generic name this species should bear. Allman (I864a) erected the genus Heteractis (later he changed it to Heterostephanus) for this species because of the peculiar ringed nature of the proximal 
tentacles. Recently the species has been redescribed by Broch as Corymorpha (Euphysa) annulicornis. This raises the question of what name the species should bear.

The capitate oral tentacles, the moniliform aboral tentacles, the backwardly directed papillae, the few frustules, the almost sessile gonophores and the characters of the medusa all apparently justify the separation of this species from Corymorpha. Indeed, the medusae have been kept under different genera, viz. Corymorpha (Steenstrupia) and Euphysa.

The separation seems justified when we compare the hydroid of C. nutans with the hydroid of the present species, but if all other species of Corymorpha are taken into consideration it appears evident that the so-called generic characters of Heterostephanus are possessed by other species of Corymorpha.

C. obvoluta Kramp I933 possesses, like C. annulicornis, moniliform proximal tentacles, sessile gonophores and backwardly directed papillae. It differs in having (among other characters) fixed gonophores, a well-developed periderm and moniliform oral tentacles. The relations of $C$. obvoluta to other Corymorphinae has been fully discussed by Kramp (1933), and so they need not be discussed here.

The chief difference distinguishing medusae of the genus Steenstrupia from Euphysa is the presence of an apical projection to the umbrella which is perhaps more suitable as a specific character than as a generic one.

It may be that all species of Euphysa are liberated from Corymorpha hydroids with moniliform aboral tentacles, but at present it is premature to lay too much stress on the significance of these annulations because the hydroids of all Euphysa medusae (except Corymorpha annulicornis and Dahlgrenella farcta) are unknown. For the present there is no justification for separating Euphysa from Corymorpha, and the species described here has been referred to as $C$. annulicornis. Now that the hydroid has been linked with the medusa Euphysa aurata Forbes the name of both hydroid and medusa must become Corymorpha aurata (Forbes 1848) ${ }^{\star}$ if the dual classification is eventually superseded.

Miles (1937) founded his genus Dahlgrenella chiefly on the peculiar asexual reproduction of his hydroid. It has been shown by Broch (1937) and in the present paper that budding from the stolon takes place normally in Corymorpha annulicornis, and there is now no reason why the species should not be included in the genus Corymorpha as C. farcta. Even if it should become necessary to remove these species from Corymorpha, then the claims of Euphysa Forbes I848 and Heterostephanus Allman I864 would have priority over Dahlgrenella Miles 1937, and also over Hipolytus Murbach 1899. The medusa liberated from Corymorpha farcta is a typical Euphysa and may possibly be the immature stage of E. virgulata A. Agassiz 1865 which is common along the American North Atlantic coast. Opinion is divided as to whether

\footnotetext{
* Corymorpha Sars I835 has priority over Euphysa Forbes I848, and the species name:
} "aurata" Forbes I848 has priority over "annulicornis" Sars I859. 
this species is distinct from E. aurata (see Mayer, I9Io, p. 35). The hydroids Corymorpha annulicornis and C. farcta are very closely related and may prove to be identical.

\section{Campanulina paracuminata n.sp.}

A small colony of a Campanulina was found on a clinker trawled in the Cattewater, Plymouth, on February 4 I936. As the colony was not reproducing it was kept in a finger bowl and fed at intervals. On October 3 the colony was transferred to the apparatus described by Rees \& Russell (1937). Here the polyps were able to feed more satisfactorily and more rapidly, and by March 7 I937, more than a year after its capture, the colony was in a thriving condition with about fifty hydranths. Gonophores were observed for the first time on April I5 1937, and two days later medusae were liberated.

The trophosome of the hydroid appeared to be almost identical with Campanulina acuminata (Alder), but my colony was less branched than the latter and very rarely possessed more than two polyps on the same hydrocaulus. The structure of the newly liberated medusa showed that the hydroid was distinct from C. acuminata.

THE HYDROID. The stems were slender rising to a height of $\mathrm{I} \cdot 5-2.5 \mathrm{~mm}$. from a branched creeping stolon. The stems were imperfectly annulated throughout their length, being $0.05 \mathrm{~mm}$. in diameter. The hydrocaulus carried one or two hydranths, the second hydranth usually arising just below the hydrotheca of the terminal hydranth. The hydrothecae were cylindrical, square below and tapering to a fine point above (Fig. Io $a$ ). Their perisarc was thin and finely striated along their length; they were $0.38-0.42 \mathrm{~mm}$. long by $0.09-$ $0.1 \mathrm{~mm}$. wide. The hydranth was very extensile and might extend to a height of I. I mm. from the base of the hydrotheca. There were about twenty tentacles around the base of a bluntly conical hypostome. These were united at the base by a well-developed membranous web. This web usually contained a number of large bean-shaped nematocysts approximately $0.015 \mathrm{~mm}$. in length (Fig. Io $b$ ). With chlorazol black $\mathrm{E}$ these bodies stain a dense blue-black and can then be seen in numbers scattered in the coenosarc of the stolon and hydrocaulus and also in the body. Their number and arrangement was never constant; very few were present in the earliest polyps seen. The tentacles extended to a maximum length of $0.6 \mathrm{~mm}$. They had an endodermal core of a single row of cells, and the nematocysts were irregularly distributed. The hydranths could not be distinguished from those of Campanulina acuminata with which they were compared in the living condition. Both colonies were grown in the laboratory, and their mode of branching may not be typical of colonies obtained from nature.

Gonophores were observed on April I5. These were borne on the hydrocauli just below the hydranths (Fig. Io $a$ ). The fully developed gonophores were large and cylindrical and attached to the hydrocaulus by an imperfectly ringed stalk of varying length (but always shorter in length than the gonotheca itself). 


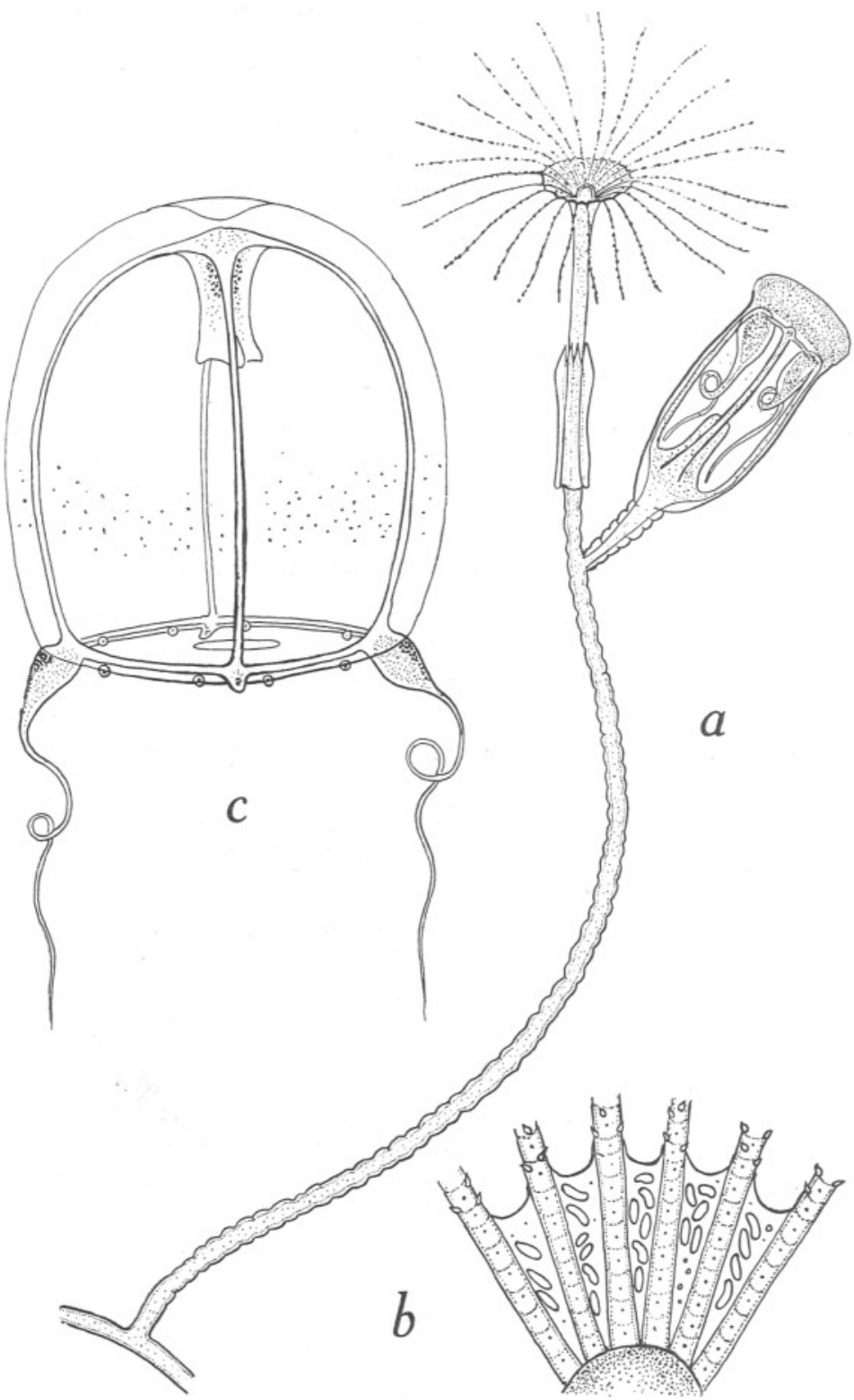

Fig. Io $a-c$. Campanulina paracuminata n.sp.: $a$, single polyp with a fully developed gonophore, Plymouth, 4 . ii. $37 ; b$, a small portion of the web of a hydranth showing the beanshaped nematocysts, Plymouth, 20. iii. $37: c$, newly liberated medusa with a diameter of I.I mm., Plymouth, 22. ii. 37. 
The gonotheca and stalk were $0.75^{-I} \cdot \mathrm{I} \mathrm{mm}$. in length, while the diameter was $0.3-0.4 \mathrm{~mm}$. The gonophore contained one medusa (rarely two), borne on a thin blastostyle which enlarged distally to form a distinct cap to the gonotheca. When fully developed the medusa escaped from the gonotheca partially by its own efforts and by partial collapse of the thin membranous gonotheca which regained its shape once the medusa came out.

The Medusa. The newly liberated medusa was of a deep bell shape a little higher than wide (Fig. Io c). It was $\mathrm{I} \cdot 4 \mathrm{~mm}$. high and I.I mm. in diameter. The jelly was moderately thick and had a slight depression at the apex. There was a conspicuous band of nematocysts on the exumbrella just below the middle or widest part. The velum was broad. The stomach had a slight apical projection; it was short and quadrangular in section; the mouth had four simple lips. The four radial canals and ring canal were narrow. There were two opposite perradial tentacles with elongated bulbs and two smaller perradial opposite bulbs without tentacles. There were eight closed globular marginal vesicles, adradial in position, each with a single concretion. There were no excretory pores.

This species is more closely related to Campanulina acuminata (Alder I857) than to any other known species of Campanulina. C. tenuis van Beneden 1847 was regarded by Alder as identical with his $C$. acuminata, but even if (judging from van Beneden's figures) it may possibly prove to be distinct from $C$. acuminata, it is certainly quite distinct from my species. A comparison of the trophosome of my species with that of living $C$. acuminata, kindly sent to Plymouth from Cullercoats by Dr H. O. Bull, revealed no visible difference between the trophosome of the two species. The C. acuminata sent by Dr Bull was kept for six months under the same conditions as my species. Both colonies produced gonophores at the same time and so it was possible to compare the newly liberated medusae. The essential differences between the two species are indicated below.

\begin{tabular}{|c|c|c|}
\hline & $\begin{array}{c}\text { Campanulina acuminata } \\
\text { (Alder) }\end{array}$ & $\begin{array}{c}\text { Campanulina paracuminata } \\
\text { n.sp. }\end{array}$ \\
\hline & Medusa & Medusa \\
\hline Umbrella. & $\begin{array}{l}\text { Deep bell-shaped with a } \\
\text { fairly thick jelly. No } \\
\text { apical depression. }\end{array}$ & $\begin{array}{l}\text { Deep bell-shaped a little } \\
\text { higher than wide; jelly } \\
\text { less thick. Apical de- } \\
\text { pression present. }\end{array}$ \\
\hline Nematocysts. & $\begin{array}{l}\text { Scattered over the whole } \\
\text { exumbrella. }\end{array}$ & $\begin{array}{l}\text { Confined to a band around } \\
\text { the lower middle part } \\
\text { of the exumbrella. }\end{array}$ \\
\hline Colour of subumbrella. & Vivid yellowish green. & Vivid bluish green. \\
\hline Colour of stomach. & Colourless. & Reddish yellow. \\
\hline Colour of tentacles. & $\begin{array}{l}\text { Yellow with two lateral } \\
\text { strips of blue-black. }\end{array}$ & $\begin{array}{l}\text { Yellow with a single cen- } \\
\text { tral strip of blue-black } \\
\text { pigment. }\end{array}$ \\
\hline Height. & $\mathrm{I} \cdot 6 \mathrm{~mm}$. & $\mathrm{I} \cdot 4 \mathrm{~mm}$. \\
\hline Diameter. & $\mathrm{I} \cdot 6 \mathrm{~mm}$. & $\mathrm{I} \cdot \mathrm{I} \mathrm{mm}$. \\
\hline
\end{tabular}


Wright (I86I) reared the first polyps of a webbed Campanulina hydroid from the planulae of Aequorea vitrina Gosse. He declared that, as far as he could recall, the young form which he reared from $A$. vitrina was identical with the hydroid of Campanulina acuminata. Strong (1925) has reared the first polyps of an Aequorea, A. victoria (Murbach \& Shearer 1903), giving the hydroid the name Campanulina membranosa.

I am much indebted to $\mathrm{Mr} \mathrm{F}$. S. Russell for permission to make use of his unpublished observations on the life history of $C$. acuminata. Several young medusae found in the plankton at Plymouth, corresponding to the newly liberated medusae of $C$. acuminata but in later stages of development, leave no doubt that the medusa develops into a species of Aequorea. One specimen found on May 23 I934 was I. $8 \mathrm{~mm}$. high by $2.5 \mathrm{~mm}$. wide and had a bellshaped umbrella a little wider than high and a fairly thick jelly of uniform thickness. It possessed four radial canals, four fully developed tentacles, four small interradial tentacles and eight adradial rudiments. The stomach was short, quadrangular in section, with four simple well-developed oral lips. In colour it agreed exactly with the newly liberated medusa of $C$. acuminata.

Another specimen found on November 7 I935 was 4. I mm. in diameter. It was in a much more advanced stage than the previous specimen. The umbrella was dome-shaped with a thick apical jelly becoming thin towards the margin. The stomach reached to about half the height of the subumbrellar cavity and its oral lips were further developed. It possessed eight complete radial canals and eight developing canals. There were four radial tentacles, four interradial tentacles, eight adradial tentacles and sixteen rudiments of tentacles between every two tentacle bulbs. The marginal vesicles were twenty-six in number with concretions varying from one to four in number. The subumbrella was a bright yellowish green in colour, and the tentacle bulbs were yellow with two lateral strips of blue-black pigment. The specimen had the appearance and characters of young Aequorea and was identified as such. Campanulina acuminata and the hydroid of Aequorea vitrina are sufficiently related to Campanulina paracuminata $\mathrm{n}$.sp. to permit the supposition that the medusa liberated from $C$. paracuminata develops into a species of Aequorea. Our knowledge of the various species of Aequorea is still very unsatisfactory, and I have therefore placed this species provisionally in the genus Campanulina van Beneden I847 as defined by Hincks (I868). *

The species may be defined as follows:

\section{Campanulina paracuminata n.sp.}

Stem slender, more or less branched, imperfectly annulated throughout, branches developed on the hydrocaulus a little below the hydranth. Hydrothecae thin, membranous, finely striated longitudinally, elongate pod-shaped, square below and tapering to a fine point above. Polyps extensile with about

* It is not proposed here to discuss the various so-called species of Campanulina which have been referred to this genus. 
twenty tentacles, united for about one-fifth of their length by a membranous web with bean-shaped nematocysts embedded in it.

Gonothecae large, cylindrical, with an imperfectly ringed stalk, borne laterally on the primary stems.

Medusa, pale bluish green, umbrella deep bell-shaped, a little higher than wide with a band of nematocysts confined to the lower middle part of the subumbrella and with an apical depression. Stomach short, quadrangular, with four simple lips. Two opposite marginal tentacles and two bulbs without tentacles; bulbs yellow with a single central strip of blue-black pigment. Marginal vesicles adradial, each with one concretion.

\section{NOTES ON OTHER HYDROMEDUSAE}

Boreohydra simplex Westblad 1937.

Ten specimens of this interesting hydroid were collected on August 9 I937 at Ypsøsund, Herdla, at a depth of $70 \mathrm{~m}$. The specimens were $\mathrm{I} \cdot 0-\mathrm{I} \cdot 75 \mathrm{~mm}$. in length and the oral tentacles were four in number. Except for their slightly greater size, the specimens differed in no respect from the description given by Westblad (I937). He found the species in two localities on the Norwegian coast, in the Ramfjord and at Tromsö. Eleven specimens were found by Dr Jöran Hult in the Balsfjord, Tromsö; they were identical with my species from Herdla.

Stauridium productum Wright 1858 .

Synonyms: Coryne cerberus Gosse 1853. Perinema cerberus Stechow I923.

A colony of this hydroid was grown from a stolon on a stem of Tubularia indivisa obtained at Bognøstrømmen on August I4 I937. The stem of the Tubularia, which also had other hydroids growing on it, was placed in a similar apparatus to that described by Rees \& Russell (1937), which Professor Brinkmann had specially set up for my use. The polyps which I reared from this colony at Herdla and later at Plymouth* were very similar to those figured by Hartlaub (I895). The development of the hydranth is quite distinct from that of Staurocoryne filiformis Rees 1936. The developing hydranth first grows three or four capitate oral tentacles, and next the four or five filiform tentacles at the proximal end are developed (Fig. I I $a$ ). At this stage the hydranths look exactly like Coryne cerberus Gosse, and I agree with Hartlaub that the two species are identical. The young hydranth corresponding to C. cerberus had a length of $0.25 \mathrm{~mm}$. and a diameter of 0.II mm. Additional whorls of tentacles (rarely more than one or two) are developed between the oral whorl and the filiform whorl. In the colony I reared, most hydranths never developed more

* Three species of hydroid were brought back to Plymouth from Herdla in a thermos flask. These were Bougainvillia muscoides, Stauridium productum and a species of Syncoryne; they are still alive in my beakers (28. ii. 38 ). 
than two whorls of capitate tentacles (Fig. II $b$ ). The oral whorl developed five or six tentacles in all; this agrees with Hartlaub's observations on this species. No medusa buds have developed to date (28. ii. $\left.3^{8}\right)$.

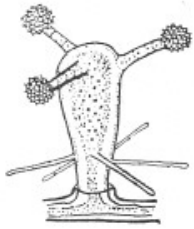

$a$

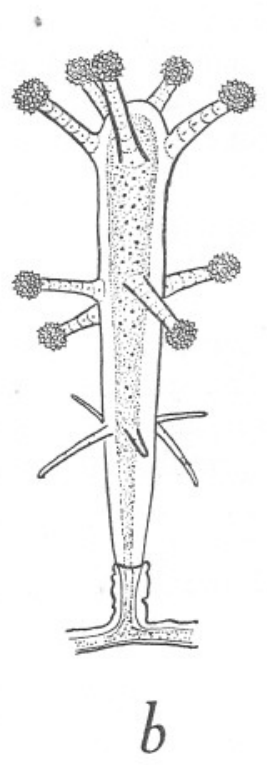

Fig. II $a, b$. Stauridium productum: $a$, young hydranth, Herdla, 20 . viii. $37 ; b$, fully developed hydranth, Herdla, 20. viii. 37 .

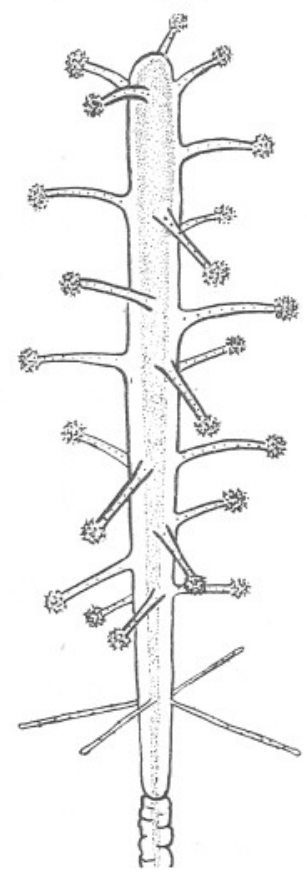

Fig. I2. Staurocoryne filiformis; single hydranth, Plymouth, 5.iv. 37.

Measurements of this colony are given be'ow:

Measurements in $\mathrm{mm}$.

$\begin{array}{llll}\text { Length of hydranth } \ldots & \ldots & \ldots & \text { I.O }-\mathrm{I} \cdot 8 \\ \text { Diameter of hydranth } \ldots & \ldots & \ldots & \text { O.I5-O.23 } \\ \text { Diameter of hydrocaulus } & \ldots & \ldots & \text { O.IO } \\ \text { Diameter of stolon } \ldots & \ldots & \ldots & 0.15 \\ \text { Total length of oral tentacle } & \ldots & \ldots & 0.20-0.3\end{array}$

The trophosome of the hydroid can easily be distinguished from Staurocoryne filiformis by its more delicate growth, the smaller hydranths, the few whorls of tentacles and by the development of the whorl of filiform tentacles immediately after the oral whorl.

Staurocoryne filiformis Rees 1936.

A small colony of this hydroid was found on a Pecten shell dredged from New Grounds, Plymouth Sound, on March I6 1937. Previously this hydroid was only known from a colony reared in the Plymouth Laboratory (Rees, 
I936). The colony from nature differed from that reared in the laboratory only in the slightly smaller size of the hydranths and in the more irregular distribution of the tentacles (Fig. I2). There were four filiform tentacles which later increased to five in number. They carried a few scattered nematocysts. Identification was verified when the colony developed styloid gonophores two months later.

\section{SUMMARY}

The newly liberated medusa of Perigonimus muscoides $M$. Sars has been found to be a Bougainvillia. A specimen from the plankton points to the extreme probability that it can be regarded as synonymous with a previously described medusa, B. nordgaardi (Browne). The name of both hydroid and medusa now becomes B. muscoides (M. Sars I846).

The systematic importance of the above discovery is discussed, and the genus Rhizorhagium M. Sars I877 is redefined to include all those species of "Perigonimus" with fixed gonophores, viz. Rhizorhagium roseum, $R$. sarsi, $R$. antarcticum, $R$. formosum, and a new species, $R$. album, from the Cornish coast.

Variations in the form of the hydroid of Leuckartiara octona are described. The newly liberated medusa of Perigonimus abyssi G. O. Sars is figured for the first time and the species referred to the genus Leuckartiara.

A new Bimeria-like hydroid, Thamnostoma russelli, is described. The characters of the medusa indicate that it belongs to the genus Thamnostoma Haeckel, and the characters of the hydroid show that the genera Thamnitis and Thamnostoma must be united.

Corymorpha annulicornis $M$. Sars is redescribed from living specimens and the medusa is shown to be Euphysa aurata Forbes. It must henceforth be known as Corymorpha aurata (Forbes).

A new species of Campanulina, $C$. paracuminata, with its young medusa is described from Plymouth.

Notes are included on Boreohydra simplex, Stauridium productum and Staurocoryne filiformis.

Certain points in the synonymy of all these species are discussed.

\section{REFERENCES}

Agassiz, A., I865. Illustrated catalogue of the Museum of Comparative Zoology at Harvard College. No. II. North American Acalephae, pp. I-234.

Alder, JoshuA, I857. A catalogue of the zoophytes of Northumberland and Durham. Trans. Tyneside Nat. Field Club, Vol. III, pp. 93-I62.

- I862. Supplement to a catalogue of the zoophytes of Northumberland and Durham. Trans. Tyneside Nat. Field Club, Vol. v, pp. 225-47.

Allman, G. J., I863. Notes on the Hydroida. Ann. Mag. Nat. Hist., Ser. 3, Vol. xI, pp. I-I2.

- I864 a. On the construction and limitation of genera among the Hydroida. Ann. Mag. Nat. Hist., Ser. 3, Vol. XIII, pp. 345-80.

- 1864 b. Notes on the Hydroida. Ann. Mag. Nat. Hist., Ser. 3, Vol. xIv pp. 57-64. 
Allman, G. J. I87i-2. A Monograph of the Gymnoblastic Hydroids, pp. I-450. Ray Society.

Beneden, P. J. van, I866. Recherches sur la faune littorale de Belgique. Mém. Acad. R. Belgique, Tome xxxvI, pp. I-207.

Bonnevie, KRISTINe, I898. Neue norwegische Hydroiden. Bergens Mus. Aarb., I898, No. V, pp. I-I 5 .

- I899. Hydroida. Norwegian North-Atlantic Expedition 1876-I878, pp. I-I03. Christiania.

BRINK, A., I925. Beiträge zur Herstellung einer rationellen Hydroidensystematik. Tijdschr. ned. dierk. Ver., Ser. 2, Vol. xIx, Pts. 3-4, pp. I26-65.

Broch, Hjalmar, I905. Nordsee-Hydroiden. Bergens Mus. Aarb., 1905, No. vi, pp. I-25.

- 1909. Die Hydroiden der arktischen Meere. Fauna Arctica, Bd.v, Jena, pp. I27-248.

- I9I I. Fauna droebachensis. I. Hydroider. Nyt. Mag. f. Naturvid., Bd. 49, Kristiania, pp. I-46.

- I916. Hydroida (Part I). Danish Ingolf-Expedition, Vol. v, pp. I-66. Copenhagen.

- I928. Hydrozoa, I. Die Tierwelt der Nord- und Ostsee, Lief. xIII, Teil III $b$, pp. I-94.

- 1937. Hydroidenuntersuchungen. VII. Corymorpha (Euphysa) annulicornis M. Sars 1859. Norske Videnskaps-Acad. Oslo I. Mat.-Naturv. Klasse, 1937, No. 8 , pp. I-32.

Browne, E. T., I896. On British hydroids and medusae. Proc. Zool. Soc. London, pp. 459-500.

- I903. Report on some medusae from Norway and Spitzbergen. Bergens Mus. Aarb. 1903, No. IV, pp. I-36.

- 1905. A report on the medusae found in the Firth of Clyde (I90I-I902). Proc. Roy. Soc. Edinburgh, Vol. xxv, pt. Ix, pp. 738-78.

- 1907. The hydroids collected by the Huxley from the north side of the Bay of Biscay in August 1906. Fourn. Mar. Biol. Assoc., Vol. viII, No. I, pp. 15-36.

BRÜCKNER, ERICH, I9I4. Beitrag zur Kenntnis von Perigonimus cidaritis Weisman, und Gemmaria implexa var. neapolitana Hargitt. Z. wiss. Zool. Leipzig, Bd. CxI, pp. $445-505$.

BUSCH, WILHELM, I85I. Beobachtungen über Anatomie und Entwickelung einiger Wirbellosen Seethiere, pp. I-I43. Berlin.

Calkins, G. N., I899. Some hydroids from Puget Sound. Proc. Boston Nat. Hist. Soc., Vol. xxviII, pp. 333-67.

FEWKES, J. W., I889. New Invertebrata from the coast of California. Bull. Essex Inst., Vol. XxI, pp. 99-I46.

Forbes, EDWARD, I848. A Monograph of the British naked-eyed Medusae, pp. I-I04. Ray Society.

Fraser, C. McLean, 1937. Hydroids of the Pacific Coast of Canada and the United States. Univ. Toronto Press.

Gosse, P. H., I853. A Naturalist's Rambles on the Devonshire Coast, pp. I-448. London: John van Voorst.

Gudger, E. W., I928. Association between Sessile Colonial Hydroids and Fishes. Ann. Mag. Nat. Hist., Ser. Io, Vol. I, pp. I-48.

Haeckel, ERnSt, I879. Das System der Medusen, pp. I-672.

Hartlaub, C., I895. Polypen und Quallen von Stauridium productum Wright und Perigonimus repens Wright. Zeit.f. wiss. Zool., Bd. LXI, pp. I42-62.

- I9I I. Nordisches Plankton. Lief. 6, XII, Craspedote Medusen. Teil I, Lief. 2, Familie III, Margelidae, pp. I37-235.

- I914. Nordisches Plankton. Lief. 6, XII, Craspedote Medusen. Teil I, Lief. 3, Familie IV, Tiaridae, pp. 237-363. 
Heath, Harold, I9Io. The association of a fish with a hydroid. Biol. Bull., Vol. xix, No. 2, I910, pp. 73-8.

Hickson, S. J. \& Gravely, F. H., I907. Coelenterata II. Hydroid zoophytes. Nat. Antarct. Exped., I90I-4, Nat. Hist. III, London, Brit. Mus., 34 pp. 4 pls.

Hincks, Thomas, I868. A History of the British Hydroid Zoophytes, pp. I-338. London: John van Voorst.

JÄDERHOLM, E., I909. Northern and Arctic invertebrates in the collection of the Swedish State Museum. IV. Hydroiden. Kungl. Svenska Vetenskap. Handl., Bd. 45 , No. I, pp. I-I 24.

KRAMP, P. L., I9II. Reports on the hydroids collected by the Denmark Expedition at north-east Greenland. Danmark-Eksped. til Grönlands Nordöstkyst 1906-8, Bd. 5, Köbenhavn.

- I9I4. Conspectus Faunae Groenlandica. Hydroider. Meddel. om Grönland, xxIII, Köbenhavn.

- 1926. Medusae. Part II. Anthomedusae. Danish Ingolf-Expedition, Vol. v, Part IO, pp. I-IO2.

- 1927. The Hydromedusae of Danish waters. Mem. Acad. Sci. Lett. Danemark, Sect. Sci., Ser. 8, Tome xiI, No. I, pp. I-290.

- I932 a. The Godthaab Expedition, 1928. Hydroids. Meddel. om Gronland, Bd. 79, No. I, pp. I-86.

- I932b. Hydroids collected in west Greenland fjords in I9I I and I912. Meddel. om Gronland, Bd. 9I, No. 3, pp. I-34.

- r933. Coelenterata, Ctenophora and Chaetognatha. Meddel. om Gronland, Bd. I04, No. I I, pp. I-20.

- 1935. Polypdyr (Coelenterata). I. Ferskvandspolypper og Goplepolypper. Danmarks Fauna, 4I, pp. I-207, Figs. I-8I.

- 1937. Polypdyr (Coelenterata). II. Golper. Danmarks Fauna, 43, pp. I-223, Figs. I-90.

- I938. Marine Hydrozoa. Hydroida. The Zoology of Iceland, Vol. II, Pt. 5a. Copenhagen.

Kramp, P. L. \& Damas, D., I925. Les Méduses de la Norvège. Vidensk. Medd. Dansk naturh. Foren. Bd. 80, pp. 217-324.

Leloup, E., I932. Une collection d'Hydropolypes appartenant á l'Indian Museum de Calcutta. Rec. Indian Museum, Vol. xxxiv, Part II, pp. I3I-70.

Levinsen, G. M. R., I892. Om Fornyelsen af Ernaeringsindividerne hos Hydroiderne. Vidensk. Medd. Dansk naturh. Foren. Kjöbenhavn, pp. I2-3I.

- I893. Meduser, Ctenophorer og Hydroider fra Grönlands Vestkyst. Vidensk. Medd. Dansk naturh. Foren. Kjöbenhavn, pp. I-70.

Linko, A., I904. Zoologische Studien im Barents-Meere. Zool. Anz., Bd. xxviII, pp. $210-20$.

MAYer, A. G., I9Io. Medusae of the World. Vol. I. Hydromedusae, pp. I-230.

MiLES, S. S., I937. A new genus of hydroid and its method of asexual reproduction. Biol. Bull., Vol. LxxII, pt. 3, pp. 327-33.

MurBaCH, L., I899. Hydroids from Wood's Hole, Mass. Hipolytus peregrinus, a new unattached Marine Hydroid: Corynitis Agassizii and its medusa. Quart. fourn. Micr. Sci., London, Vol. xLII, pt. 3, N.S., pp. 34I-60.

Neppi, Valeria \& Stiasny, Gustav, I9I3. Die Hydromedusen des Golfes von Trieste. Arb. Zool. Inst. Univ. Wien u. Zool. Stat. Trieste, Bd. xx, pp. 23-9o.

REES, W. J., I936. On a new species of hydroid Staurocoryne filiformis, with a revision of the genus Staurocoryne Rotch 1872. Fourn. Mar. Biol. Assoc., Vol. XxI, pp. I35-42.

- I937. On a remarkable process of bud formation in a gymnoblastic hydroid (Heterostephanus sp.). Fourn. Mar. Biol. Assoc., Vol. xxi, pp. 747-52. 
REES, W. J. \& RUSSELL, F. S., I937. On rearing the hydroids of certain medusae, with an account of the methods used. Fourn. Mar. Biol. Assoc., Vol. xxir, No. I, pp. 6I-82.

Ritchie, James, I9I3. A New British commensal hydroid, Perigonimus abyssi G. O. Sars. Fisheries Ireland Sci. Invest. I913, I, I913, pp. I-3.

Russell, E. S., I906. On Trichorhiza, a new hydroid genus. Proc. Zool. Soc., London, February 1906, pp. 99-I01.

- 1907. The Atractylis coccinea of T. S. Wright. Ann. Mag. Nat. Hist., Ser. 7, Vol. $\mathrm{xx}, \mathrm{pp} .52-5$.

SARS, Michael, I835. Beskrivelser og Iagt, etc., pp. I-8I. Bergen.

- I846. Fauna Littoralis Norvegiae, I, pp. I-94. Christiania.

- 1857. Bidrag til kundskaben om Middelhavets Litoral-Fauna. Nyt. Mag. Naturvid., Vol. Ix, pp. I IO-64.

- 1859. Udtog af en Afhandling, etc. Forhandl. $i$ Vid. Selsk. $i$ Christiania, 1859, pp. 96-105.

- 1877. New and little known Coelenterates. Fauna Littoralis Norvegiae, III, pp. I-48, Taf. I-2.

SARS, G. O., 1873. Bidrag til Kundskaben om Norges Hydroider. Vidensk.-Selsk. Forhandl. for 1873 , pp. I-62.

Schydlowsky, A., I90I. Les Hydraires de la Mer Blanche le long du littoral des Iles Solowetzky. Trav. Soc. Nat. Univ. Imp. Kharkow, Vol. xxxvi, pp. I-276.

Stechow, E., I9I9. Zur Kenntnis der Hydroidenfauna des Mittelmeeres, Amerikas und anderer Gebiete. Zool. Fahrb. Syst., Bd. 42, pp. I-I72.

- 1923. Zur Kenntnis der Hydroidenfauna des Mittelmeeres, Amerikas und anderer Gebiete. Zool. Fahrb. Syst., Bd. 47, pp. 29-270.

- I929. UUber Symbiosen von Hydroiden mit Polychaeten. Zool. Anz., Bd. 86, Heft 5-6, pp. 150-3.

Strong, L. H., 1925. Development of certain Puget Sound hydroids and medusae. Pub. Puget Sound Biol. Stat., Vol. III, pp. 383-99.

Torrey, H. B., I902. The Hydroida of the Pacific coast of North America, with especial reference to the species in the collection of the University of California. Univ. Calif. Publ. Zool., Vol. I, pp. I-I04.

Totton, A. K., I930. Hydroida. Brit. Antarct. ("Terra Nova") Exp., I9 Io, Nat. Hist. Rep., Zool., Vol. v, Coelenterata, pp. I3I-252.

WeStblaD, EINAR, I937. Boreohydra simplex n.gen., n.sp., ein Solitärpolyp von der norwegischen Küste. Arch. f. Zool., Bd. xxIx, No. 7 .

WRIGHT, T. STRETHILL, I857. Observations on British zoophytes and on the prehensile apparatus of Spio seticornis. Edinb. New Phil. Fourn., N.S., Vol. vi.

- I858. Observations on British zoophytes. Edinb. New Phil. Fourn., N.S., Vol. vir.

- 1861. Observations on British Protozoa and zoophytes. Ann. Mag. Nat. Hist., Ser. 3, Vol. viII, pp. I20-35.

- I863. Observations on British zoophytes. Quart. Fourn. Micr. Sci., N.S., Vol. III, pp. 47-52. 